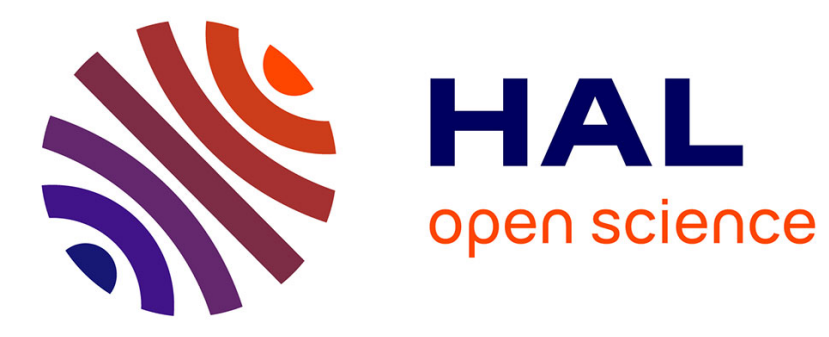

\title{
Solvent-free synthesis of nitrones in a ball-mill
}

Evelina Colacino, Pierrick Nun, Francesco Maria Colacino, Jean Martinez, Frédéric Lamaty

\section{To cite this version:}

Evelina Colacino, Pierrick Nun, Francesco Maria Colacino, Jean Martinez, Frédéric Lamaty. Solvent-free synthesis of nitrones in a ball-mill. Tetrahedron, 2008, 64, pp.5569-5576. 10.1016/j.tet.2008.03.091. hal-00278417

\section{HAL Id: hal-00278417 https://hal.science/hal-00278417}

Submitted on 1 Feb 2021

HAL is a multi-disciplinary open access archive for the deposit and dissemination of scientific research documents, whether they are published or not. The documents may come from teaching and research institutions in France or abroad, or from public or private research centers.
L'archive ouverte pluridisciplinaire HAL, est destinée au dépôt et à la diffusion de documents scientifiques de niveau recherche, publiés ou non, émanant des établissements d'enseignement et de recherche français ou étrangers, des laboratoires publics ou privés. 


\title{
Solvent-free synthesis of nitrones in a ball-mill
}

\author{
Evelina Colacino ${ }^{\mathrm{a}}$, Pierrick Nun ${ }^{\mathrm{a}}$, Francesco Maria Colacino ${ }^{\mathrm{b}}$, Jean Martinez ${ }^{\mathrm{a}}$, Frédéric Lamaty ${ }^{\mathrm{a}, *}$ \\ a Institut des Biomolécules Max Mousseron, UMR 5247 CNRS-Université Montpellier 1 et Université Montpellier 2, Place Eugène Bataillon, 34095 Montpellier cedex 05, France \\ ${ }^{\mathrm{b}}$ Department of Experimental and Clinical Medicine, University of Magna Graecia 88100 Germaneto, Catanzaro, Italy
}

Keywords:

Waste prevention

Solid-state reactions

Mechanochemical activation

Nitrones

Solvent-free reactions

\begin{abstract}
A B S T R A C T
Various C-aryl and C-alkyl-nitrones were synthesized within $0.5-2 \mathrm{~h}$ via condensation of an equimolar amount of aldehydes and $\mathrm{N}$-substituted-hydroxylamines under solvent-free conditions in a ball-mill apparatus. Reactions can be performed without the need of excluding air and moisture and yields the expected products with no need for further purification. The study has been complemented by Differential Scanning Calorimetry (DSC) and solid-state ${ }^{13} \mathrm{C}$ MAS nuclear magnetic resonance experiments. We have also studied the temperature profile during the reaction. A comparative study with the corresponding solvent-free microwave activated reaction showed the superiority of the ball-milling method; 31 examples are described, including the synthesis of the anti-aging agent $C$-phenyl- $N$-tert-butyl nitrone (PBN) and one of its analogues C-2-pyridyl- $N$-tert-butylnitrone (2-PyBN).
\end{abstract}

\section{Introduction}

Ball-milling is a mechanochemical technique that is widely applied to the grinding of minerals into fine particles and to the preparation and modification of inorganic solids., ${ }^{1,2}$ Ball-mill chemistry is of interest because it takes place under mild conditions, in the absence of solvent, and in environmentally friendly conditions. In the last years, this technique has found interest in synthetic organic chemistry., ${ }_{5}^{3,4}$ The reported examples include functionalization of fullerenes, ${ }^{5}$ reductive benzylation of malonitrile, ${ }^{6}$ protection of amines, ${ }^{7}$ Knoevenagel reaction, ${ }^{8}$ aldol condensation ${ }^{9}$ and its asymmetric version, ${ }^{10}$ Michael additions, ${ }^{8}$ preparation of phosphorus ylides, ${ }^{11}$ oxidative coupling of 2 -naphthol, ${ }^{12}$ and Heck-type cross-coupling reactions. ${ }^{13,14}$

We report herein the application of this non-conventional methodology for the preparation of different nitrones, which are highly valuable synthetic intermediates in organic synthesis. They behave as electrophiles toward organometallics and as 1,3-dipoles in cycloadditions. ${ }^{15}$ Recently, novel reactivities have been described. ${ }^{16-18}$ Nitrones have relevant applications as spin traps in biological studies, ${ }^{19}$ and are efficient in age-related diseases, ${ }^{20}$ due to both in vitro and in vivo ${ }^{21}$ stability of resulting nitroxide radicals. The nitrone compound reacts with a free radical to form a derivative called spin adduct. Once the adduct is formed, it is relatively stable

\footnotetext{
* Corresponding author. Tel.: +33 467143847; fax: +33 467144866

E-mail address: frederic.lamaty@univ-montp2.fr (F. Lamaty).
}

and the radical thus becomes inactivated and unable to interfere in biochemical processes and damage cellular tissues.

The most common procedures for the preparation of nitrones consist in condensation of aldehydes with $\mathrm{N}$-monosubstituted hydroxylamines, ${ }^{22-25}$ or oxidation of secondary amines or $\mathrm{N}, \mathrm{N}$ disubstituted hydroxylamine. ${ }^{15,26}$ Even though good to excellent results could be achieved in both cases, they present still some limitations, including the use of organic solvents, relatively long reaction times, use of an excess of the aldehyde to achieve high conversion, and tedious chromatographic purifications. Moreover, only a few of these procedures employed environmentally benign oxidants with metal catalysts. ${ }^{27-30}$ In order to find a more efficient and benign methodology ${ }^{31}$ for the synthesis of nitrones, we investigated solvent-free ball-mill chemistry, which is a 'highlight of green chemistry'.

\section{Results and discussion}

We chose as a model the stoichiometric reaction between benzaldehyde 1a $(0.5 \mathrm{mmol})$ and $N$-methylhydroxylamine hydrochloride $2(0.5 \mathrm{mmol})$, in the presence of sodium bicarbonate (0.5 mmol) (Scheme 1).

The mixture was introduced into a stainless steel jar $(10 \mathrm{~mL})$. The reaction vessel was closed and fixed on the vibration arms of a ball-milling apparatus, along with two stainless balls of $7.0 \mathrm{~mm}$ diameter (Retsch MM200 mixer mill, Retsch GmbH, Hann, Germany), ${ }^{7}$ using a second parallel jar to equilibrate the system. Then, both vessels were vibrated vigorously at a frequency of $30 \mathrm{~Hz}$ at room temperature. To obtain an analytical sample, the crude 


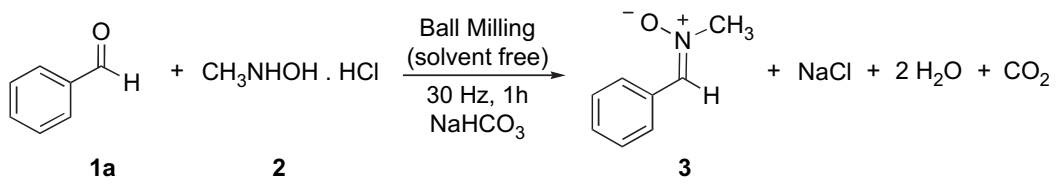

Scheme 1. Synthesis of $N$-methyl-C-phenyl nitrone 3.

mixture was recovered by following a straightforward and easy work-up procedure. A minimum amount of dichloromethane was added to the crude, filtered on cotton to eliminate $\mathrm{NaCl}$. The filtrate was evaporated affording the $N$-methyl-C-phenyl nitrone 3 in $82 \%$ yield. ${ }^{1} \mathrm{H}$ NMR of the mixture detected only the expected product with total consumption of the starting materials. For practical use, nitrone can be used without further purification to eliminate $\mathrm{NaCl}$, alternatively, the product can be recovered by precipitation of the crude from water, poor solvent for nitrones. It is common to add some $\mathrm{NaCl}$ as an additive to improve the mechanical properties of the reaction mixture, ${ }^{12}$ but in our case, it was not needed. It is important to note that under typical ball-milling conditions, the mechanical agitation process led to a slight heating of the reaction vessel, along with a slight pressure inside the vessel that was detected when opening.

It is worth mentioning that the best results were obtained when using a 1:1 starting material ratio. The use of an excess of one of the reagents is detrimental to the conversion of the reaction. During the synthesis of nitrones, the hydroxylamine function is usually activated by adding a base such as triethylamine or sodium bicarbonate in the mixture. Since dry-milling has proved to be more efficient, solid sodium bicarbonate was chosen and gave the best results. We also reacted aldehyde $\mathbf{1 e}$ and hydroxylamine hydrochloride 2 , during $2 \mathrm{~h}$ (Table 1 ), in absence of sodium bicarbonate. At the end of the experiment, the sticky crude was recovered by methanol, filtered, and the solvent evaporated. The crude was analyzed by ${ }^{1} \mathrm{H}$ NMR, using $\mathrm{CH}_{2} \mathrm{Br}_{2}$ as an internal standard. The reaction was incomplete (the conversion of aldehyde 1e was $77 \%$ ) and the ${ }^{1} \mathrm{H}$ NMR yield of nitrone $\mathbf{1 2}$ was $59 \%$. When we performed the reactions at a lower frequency $(10 \mathrm{~Hz}$ or $20 \mathrm{~Hz})$ for a period of time between $30 \mathrm{~min}$ and $2 \mathrm{~h}$, the aldehyde and hydroxylamine were still present in the crude, probably due to diminished amount of energy per impact. Ball-milling with pause resulted in lower conversion. Ball-milling experiments were again more suitable for a scale-up procedure and from a practical point of view. The stoichiometric reaction between aldehyde $\mathbf{1 b}(5.0 \mathrm{mmol})$ and $\mathrm{N}$ methylhydroxylamine hydrochloride $\mathbf{2}(5.0 \mathrm{mmol})$ in the presence of sodium bicarbonate $(5.0 \mathrm{mmol})$ after $30 \mathrm{~min}$ showed the formation of nitrone $\mathbf{8}$ in $88 \%$ yield. Unfortunately, when we run the

Table 1

Synthesis of nitrones $\mathbf{3}$ and $\mathbf{6 - 1 6}$ by condensation of various arylaldehydes $\mathbf{1 a}-\mathbf{h}$ with $\mathrm{R}^{2} \mathrm{NHOH} \cdot \mathrm{HCl} \mathrm{2,4}$, and 5

\begin{tabular}{lllllcl}
\hline $\mathrm{R}^{1}$ & & $\mathrm{R}^{2} \mathrm{NHOH} \cdot \mathrm{HCl}$ & $T(\mathrm{~h})$ & Product & $\begin{array}{l}\text { Yield (\%) } \\
\text { ball-mill }\end{array}$ & $\begin{array}{l}\text { Yield (\%) } \\
\text { microwave }\end{array}$ \\
\hline $\mathrm{C}_{6} \mathrm{H}_{5}$ & $\mathbf{1 a}$ & $\mathbf{2}$ & 1 & $\mathbf{3}$ & 82 & 72 \\
$\mathrm{C}_{6} \mathrm{H}_{5}$ & $\mathbf{1 a}$ & $\mathbf{4}$ & 1 & $\mathbf{6}$ & 88 & 80 \\
$\mathrm{C}_{6} \mathrm{H}_{5}$ & $\mathbf{1 a}$ & $\mathbf{5}$ & 2 & $\mathbf{7}(\mathrm{PBN})$ & 100 & 74 \\
$4-\mathrm{CN}-\mathrm{C}_{6} \mathrm{H}_{4}$ & $\mathbf{1 b}$ & $\mathbf{2}$ & 0.5 & $\mathbf{8}$ & 93 & 64 \\
$4-\mathrm{CN}_{-}-\mathrm{C}_{6} \mathrm{H}_{4}$ & $\mathbf{1 b}$ & $\mathbf{4}$ & 2 & $\mathbf{9}$ & 99 & n.d. \\
$4-\mathrm{NO}_{2}-\mathrm{C}_{6} \mathrm{H}_{4}$ & $\mathbf{1 c}$ & $\mathbf{2}$ & 0.5 & $\mathbf{1 0}$ & 94 & n.d. \\
$4-\mathrm{I}-\mathrm{C}_{6} \mathrm{H}_{4}$ & $\mathbf{1 d}$ & $\mathbf{2}$ & 1 & $\mathbf{1 1}$ & 100 & n.d. \\
$3-\mathrm{I}-\mathrm{C}_{6} \mathrm{H}_{4}$ & $\mathbf{1 e}$ & $\mathbf{2}$ & 1 & $\mathbf{1 2}$ & 94 & n.d. \\
$2-\mathrm{I}-\mathrm{C}_{6} \mathrm{H}_{4}$ & $\mathbf{1 f}$ & $\mathbf{2}$ & 2 & $\mathbf{1 3}$ & 100 & n.d. \\
$4-\mathrm{CH}_{3}-\mathrm{C}_{6} \mathrm{H}_{4}$ & $\mathbf{1 g}$ & $\mathbf{2}$ & 0.5 & $\mathbf{1 4}$ & 96 & n.d. \\
$4-\mathrm{CH}_{3}-\mathrm{C}_{6} \mathrm{H}_{4}$ & $\mathbf{1 g}$ & $\mathbf{4}$ & 2 & $\mathbf{1 5}$ & 88 & 65 \\
$3-\mathrm{CH}_{3}-\mathrm{C}_{6} \mathrm{H}_{4}$ & $\mathbf{1 h}$ & $\mathbf{2}$ & 2 & $\mathbf{1 6}$ & 91 & n.d. \\
\hline
\end{tabular}

${ }^{a}$ Yields of isolated pure nitrones. All reactions reached complete conversion, unless otherwise stated.

b Comparative experiment under microwave activation $3 \mathrm{~h}$ at $120^{\circ} \mathrm{C}$ (optimized conditions). same experiment on $10.0 \mathrm{mmol}$ scale, the lower substrate conversion $(68 \%)$ is a result of an inefficient mixing, showing that the $10 \mathrm{ml}$ jar was not adapted for such a scale. The milled material was qualitatively finer than the original starting materials and it accumulated on both the top and the bottom of jar. A compact layer is formed, constituted by nitrone $\mathbf{8}$ and unreacted starting materials. This avoids the impact energy from the grinding ball to be more effectively applied on the residual sample.

We also investigated the synthesis of nitrone 8 by Differential Scanning Calorimetry (DSC), running four independent experiments. First, 4-cyanobenzaldehyde 1b, $N$-methylhydroxylamine hydrochloride $\mathbf{2}$, and preceding synthesized nitrone $\mathbf{8}$ according to our methodology, were separately analyzed by DSC (warm-up rate: $10^{\circ} \mathrm{C} / \mathrm{min}$ ), and their respective melting points confirmed by thermograms. Then, we heated-up a mixture of $\mathbf{1 b}, \mathbf{2}$, and the base for $2 \mathrm{~h}$, from $24^{\circ} \mathrm{C}$ to $250{ }^{\circ} \mathrm{C}$ (warm-up rate $2^{\circ} \mathrm{C} / \mathrm{min}$ ) without stirring. This resulted in a decomposition of all the starting materials, without formation of nitrone $\mathbf{8}$, as demonstrated after ${ }^{1} \mathrm{H}$ NMR analysis of the crude, showing the necessity of the shaking movement. From the model studies, it is apparent that it is not sufficient to simply heat the reaction mixture in a vessel. Apparently, the ballmilling created conditions that are difficult to obtain under usual conditions. It is most probably the combination of pressure, heat, grinding, and stirring that provides the conditions necessary for the successful outcome of the reaction., ${ }^{1,3,7}$

The effect of three milling operating conditions has been investigated through the variation of external temperature of the vessel measured during the milling experiment for a period of $30 \mathrm{~min}$ at $30 \mathrm{~Hz}$ : (a) empty vessel; (b) reaction on $0.5 \mathrm{mmol}$ scale; and (c) reaction on $5.0 \mathrm{mmol}$ scale. For ambient milling, the starting temperature of the sample is in all cases at approximately $30^{\circ} \mathrm{C}$ and rises to nearly $44^{\circ} \mathrm{C}$ (experiment a) or $40{ }^{\circ} \mathrm{C}$ (experiments b and $\mathrm{c}$ ) at the end of the test. ${ }^{32}$ Through a heat transfer lumped parameter mathematical model, ${ }^{32}$ describing the milling apparatus, starting from its mechano-physical properties, we were able to determine that the temperature experimented inside the jar is the same as the external one.

We extended the methodology to other arylaldehydes $\mathbf{1 b}-\mathbf{h}$ in the presence of $\mathrm{N}$-methyl-, $\mathrm{N}$-benzyl-, and $\mathrm{N}$-tert-butylhydroxylamine hydrochlorides $(\mathbf{2}, \mathbf{4}$, and $\mathbf{5}$, respectively). The results are summarized in Table 1 (Scheme 2).

In all cases the reaction proceeded as a one-step condensation to give the corresponding nitrones 6-16 in nearly quantitative yields, without the need to exclude air and moisture, in a shorter reaction time than by classical methods, but with comparable yields, where excess of reagents under inert atmosphere are reacted at room temperature or under heating for 1 or 2 days. ${ }^{15,26}$

When the yields are inferior to $100 \%$, this is due to incomplete recovery of the nitrone/ $\mathrm{NaCl}$ mixture from the ball-mill jar. In all

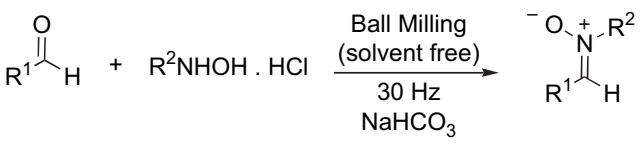

$$
\begin{aligned}
& \text { 1a-r } 2 \mathrm{R}_{2}=\mathrm{CH}_{3} \\
& \begin{array}{l}
4 \mathrm{R}_{2}=\mathrm{Bn} \\
5 \mathrm{R}_{2}=\mathrm{C}\left(\mathrm{CH}_{3}\right)
\end{array} \\
& \text { 6-31 }
\end{aligned}
$$


the cases discussed herein, full conversion to the expected product was obtained. This was further demonstrated by cross polarization/ magic angle spinning (CP/MAS) ${ }^{13} \mathrm{C}$ NMR analysis of the reaction mixture, arising from the reaction of aldehyde 1e with $\mathrm{N}$-methylhydroxylamine hydrochloride $\mathbf{2}$, in the presence of base, directly without any treatment with a solvent. Figure 1 shows three CP/MAS ${ }^{13} \mathrm{C}$ spectra. The first two correspond to the starting materials. The third one shows complete disappearance of the peaks corresponding to the starting materials and it displays resonances only
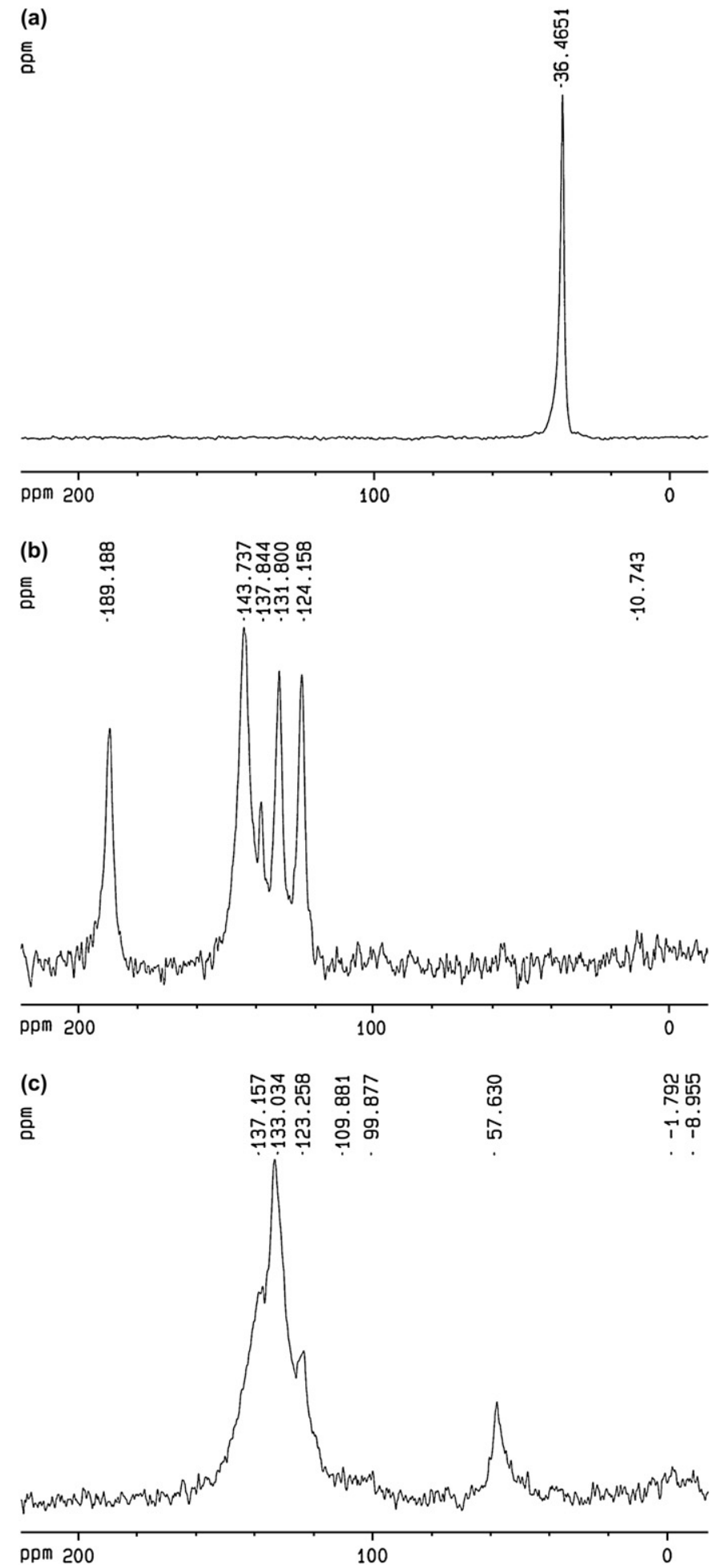

Figure 1. ${ }^{13} \mathrm{C} \mathrm{CP} / \mathrm{MAS}$ spectra of (a) $\mathrm{N}$-methylhydroxylamine hydrochloride 2; (b) 3iodobezaldehyde 1e, and (c) (Z)- $N$-(3-iodobenzylidene)methylamine $N$-oxide $\mathbf{1 2}$. for the expected nitrone 12. $N$-tert-Butyl- $\alpha$-phenyl nitrone (PBN) 7 was obtained in quantitative yield in mild conditions without observing any undesired oxidation of the hydroxylamine to nitroso compound, as previously described, during its synthesis under $24 \mathrm{~h}$ reflux conditions in dichloromethane. ${ }^{24} \mathrm{PBN}$ is one of the most studied, since it inhibits oxidation of lipoproteins, ${ }^{33}$ it displays neuroprotective activity, ${ }^{34}$ and exhibits potent antisenescent effects most notably in neurodegenerative diseases such as Parkinson's, Alzheimer's disease, and Stroke syndrome. ${ }^{21}$ The reaction proved to be general with respect to the nature of the substituent or to its position on the aromatic ring. Comparative condensation experiments were also carried out between aldehydes $\mathbf{1 b}$ and $\mathbf{1 e , f}$ using $\mathrm{N}$-methylhydroxylamine hydrochloride as-received from commercial suppliers without further purification, or after a double recrystallization from an AcOEt/EtOH mixture.

In all cases, higher yields of nitrones were obtained using recrystallized hydroxylamine $\mathbf{2}$, and total conversion of the starting materials.

To confirm the advantages of the ball-milling technology, a comparative study under optimized conditions, using a microwave synthesizer under solvent-free conditions, was undertaken. ${ }^{18,35,36}$ The yields of nitrones $\mathbf{3 , 6 - 8}$, and $\mathbf{1 5}$ dropped drastically compared to the corresponding ball-milling experiments. The reactions proceeded more slowly (up to $2 \mathrm{~h}$ ), at high temperature $\left(120^{\circ} \mathrm{C}\right.$ ) and without achieving a total conversion of the starting aldehydes $\mathbf{1 a}$, $\mathbf{1 b}$, and $\mathbf{1 g}$, maybe due to a degradation of the free hydroxylamine and to a slurry of $\mathrm{NaHCO}_{3}$ in melts, which provokes a lower yield. High yields of nitrones 3 and $\mathbf{6}$ (up to 95\%) could only be obtained in dichloromethane solution, using an excess of hydroxylamine 2 ( 2.5 equiv) under microwave irradiation. ${ }^{35}$ Purification by column chromatography was then necessary to recover the products.

To further prove the general concept, the methodology was extended to other heteroaromatic or aliphatic aldehydes. Results are summarized in Table 2. Heteroaromatic aldehydes such as 2-furfural 11, 2-thiophenylcarbaldehyde 1m, and pyridinecarbaldehydes $\mathbf{1 i}-\mathbf{k}$ were also excellent substrates. This method gave straightforward access to biologically important nitrones. For example, furylnitrone $\mathbf{2 3}$ was obtained in good yield, being reported that furylnitrones reduce infarct volume in an in vivo model. ${ }^{37}$ An analogue of the widely used spin trap $N$-tertbutyl- $\alpha$-nitrone 7 (PBN), N-tert-butyl- $\alpha$-(2-pyridyl)nitrone 22 (2PyBN), known to show enhanced complexation properties ${ }^{38}$ of metal due to its chelating pyridyl group, was obtained in good yields. Alkylaldonitrones $\mathbf{3 0}$ and $\mathbf{3 1}$, known to be thermoinstables, ${ }^{39}$ were also easily obtained in high yields too and characterized. Unfortunately, if $n$-butyraldehyde $\mathbf{1 q}$ is reacted in the

Table 2

Synthesis of heteroaromatic and aliphatic nitrones 17-32 by condensation of aldehydes 1i-r with $\mathrm{R}^{2} \mathrm{NHOH} \cdot \mathrm{HCl} \mathbf{2}, \mathbf{4}$, and $\mathbf{5}$

\begin{tabular}{|c|c|c|c|c|c|}
\hline $\mathrm{R}^{1}$ & & $\mathrm{R}^{2} \mathrm{NHOH} \cdot \mathrm{HCl}$ & $T(\mathrm{~h})$ & Product & Yield $^{\mathrm{a}}(\%)$ \\
\hline $4-\mathrm{C}_{5} \mathrm{H}_{4} \mathrm{~N}-$ & $1 \mathbf{i}$ & 2 & 2 & 17 & 96 \\
\hline $4-\mathrm{C}_{5} \mathrm{H}_{4} \mathrm{~N}-$ & $1 \mathbf{i}$ & 4 & 2 & 18 & 100 \\
\hline $4-\mathrm{C}_{5} \mathrm{H}_{4} \mathrm{~N}-$ & $1 \mathbf{i}$ & 5 & 2 & 19 & 98 \\
\hline $3-\mathrm{C}_{5} \mathrm{H}_{4} \mathrm{~N}-$ & $\mathbf{1 j}$ & 2 & 2 & 20 & 87 \\
\hline $2-\mathrm{C}_{5} \mathrm{H}_{4} \mathrm{~N}-$ & 1k & 2 & 2 & 21 & 96 \\
\hline $2-\mathrm{C}_{5} \mathrm{H}_{4} \mathrm{~N}-$ & $1 \mathbf{k}$ & 5 & 2 & 22 (2-PyBN) & 71 \\
\hline 2-Furyl- & 11 & 2 & 1.5 & 23 & 80 \\
\hline 2-Furyl- & 11 & 4 & 2 & 24 & 94 \\
\hline 2-Thiophenyl- & $1 \mathrm{~m}$ & 2 & 2 & 25 & 92 \\
\hline 2-Benzofuranyl- & 1n & 2 & 0.5 & 26 & 100 \\
\hline 2-Naphthyl- & 10 & 2 & 2 & 27 & 92 \\
\hline 2-Naphthyl- & 10 & 4 & 2 & 28 & 100 \\
\hline 3-Quinolyl- & $1 p$ & 2 & 2 & 29 & 95 \\
\hline$n-\mathrm{CH}_{3}\left(\mathrm{CH}_{2}\right)_{2}-$ & $1 q$ & 2 & 1 & 30 & 93 \\
\hline$n-\mathrm{CH}_{3}\left(\mathrm{CH}_{2}\right)_{5-}$ & 1r & 2 & 1 & 31 & 90 \\
\hline
\end{tabular}

a Yields of isolated pure nitrones. All reactions reached complete conversion unless otherwise stated. 
presence of $\mathrm{N}$-benzylhydroxylamine hydrochloride 4, (instead of $\mathrm{N}$ hydroxylamine hydrochloride 2 ) the conversion of starting materials was quantitative, but the corresponding nitrone proved to be very unstable. Moreover, during the solution condensation reaction, the yield of nitrones are known to decrease in the case of bulky $\mathrm{N}$-tert-butylnitrones compared to $\mathrm{N}$-methylnitrones. Thanks to the ball-milling technique, electronic effects or steric constraints on the aldehydes or on the hydroxylamines became negligible, the corresponding nitrones were obtained in high yields. With the exception of alkylaldonitrones $\mathbf{3 0}$ and 31, which decompose after few days, all the nitrones proved to be stable after storage at room temperature up to 1 month and more than 6 months if stored at $-18^{\circ} \mathrm{C}$. An aqueous solution of pure nitrone 8 showed no decomposition after 5 days at room temperature. Moreover, a $\mathrm{CDCl}_{3}$ solution of a pure sample of several nitrones (prepared independently) remained unchanged for weeks without equilibration to regioisomeric nitrones. ${ }^{40}$

Ball-milling conditions are undoubtedly very different from conventional conditions. Therefore we could not assume that the $E, Z$-isomeric ratio would be the same as that observed in experiments ran under conventional conditions. By a comparison of literature spectral data, we concluded that the products obtained in ball-milling conditions were identical to those already reported in literature: all the nitrones were in the more stable $Z$-form, ${ }^{41}$ with the exception of $\mathrm{N}$-(napht-2-ylmethylidene)methylamine $\mathrm{N}$-oxide 27, known to be in the $E$-form. ${ }^{42}$

\section{Conclusion}

In summary, nitrones were synthesized for the first time in a ball-mill under mechanochemical and solvent-free conditions. This protocol is promising and thus constitutes an appealing alternative both in academic research and in practical processes, being simple to perform, cheap, scalable, occurring under mild conditions, and providing only water, $\mathrm{NaCl}$, and $\mathrm{CO}_{2}$ as byproducts. The methodology is highly profitable in terms of sustainable synthesis with utmost efficiency in all respect, affording products in pure form without further purification and in high yield. The protocol described allowed the easy synthesis of nitrones, considered as good candidates for the treatment of various diseases or as useful building-blocks for the synthesis of more elaborated structures.

\section{Experimental section}

\subsection{General information}

All reagents were purchased from Aldrich Chemical Co. and used without further purification. Commercial $\mathrm{N}$-methylhydroxylamine hydrochloride $\mathbf{2}$ was crystallized twice from a mixture of AcOEt/ EtOH at $-20{ }^{\circ} \mathrm{C} .{ }^{1} \mathrm{H}$ and ${ }^{13} \mathrm{C}$ NMR analyses were performed with Bruker Avance DPX $200 \mathrm{MHz}$, Bruker Avance AM $300 \mathrm{MHz}$ or Bruker $\mathrm{AC}-400 \mathrm{MHz}$ and are reported in parts per million and calibrated using residual undeuterated solvents as an internal reference. Data are reported as: $\mathrm{br}=$ broad, $\mathrm{s}=$ singlet, $\mathrm{d}=$ =doublet, $\mathrm{t}=$ triplet, $\mathrm{q}=$ quartet, $\mathrm{m}=$ multiplet; coupling constant(s) in hertz, integration. Solid-state ${ }^{13} \mathrm{C}$ NMR spectra were recorded on a Bruker Avance AM operating at $300 \mathrm{MHz}$ with a $4 \mathrm{~mm}$ rotor size CP/MAS (cross polarization/magic angle spinning) probe. Measurements of phase-transition temperatures (Differential Scanning Calorimetry, DSC) were performed with a Netzsch differential scanning calorimeter, model 204 F1 Phoenix, and the data were evaluated using Netzsch Proteus Thermal Analysis software version 4.8.1. Samples of 4-16 mg were placed in a hermetically sealed aluminum pan; an empty pan was used as a reference. Pans were exposed to a $\mathrm{N}_{2}$ flow atmosphere. Measurements were performed by heating separately aldehyde $\mathbf{1 b}$ (6.6 $\mathrm{mg})$, hydroxylamine hydrochloride $\mathbf{2}(5.3 \mathrm{mg})$, and nitrone $\mathbf{8}$
(4.5 mg) from $24{ }^{\circ} \mathrm{C}$ to $250{ }^{\circ} \mathrm{C}$ at a rate of $10{ }^{\circ} \mathrm{C} / \mathrm{min}$, or a mixture of aldehyde $\mathbf{1 b}$ ( $7.5 \mathrm{mg}, 0.05 \mathrm{mmol})$, hydroxylamine hydrochloride 2 (4.2 mg, $0.05 \mathrm{mmol}$ ), and $\mathrm{NaHCO}_{3}\left(4.2 \mathrm{mg}, 0.05 \mathrm{mmol}\right.$ ) from $24{ }^{\circ} \mathrm{C}$ to $250{ }^{\circ} \mathrm{C}$ at a rate of $2{ }^{\circ} \mathrm{C} / \mathrm{min}$. Mass spectra (electrospray ionization mode, ESIMS) were recorded on a Platform II (Micromass, Manchester, UK) quadrupole mass spectrometer fitted with an electrospray interface. The mass spectrometer was calibrated in the positive- and negative-ion ESI mode. The samples were dissolved in $\mathrm{H}_{2} \mathrm{O} / \mathrm{CH}_{3} \mathrm{CN}(50 / 50 \mathrm{v} / \mathrm{v}$ ). FAB mass spectra and HRMS (High Resolution Mass Spectrum) were recorded on a JEOL JMS DX300-SX 102 in positive mode using NBA (3-nitrobenzylalcool) or GT (mixture of glycerol/thioglycerol $50 / 50 \mathrm{v} / \mathrm{v}$ ) as matrix. Infrared spectra were recorded by diffuse reflectance or by transmittance in $\mathrm{KBr}$ salt plates on a Nicolet Avatar 330FT-IR. Data are reported according to their group absorption regions as $\mathrm{s}=\mathrm{strong}, \mathrm{m}=$ medium, and $\mathrm{w}=$ weak. Melting points were measured on a Büchi Melting Point 510 apparatus and are uncorrected. Microwave-assisted reactions were performed in sealed vessels with a Biotage Initiator $60 \mathrm{EXP}^{\circledR}$ instrument. The temperature was measured with an IR sensor on the outer surface of the reaction vial. The Ball-milling experiments were performed in a Retsch MM200 mixer mill (Retsch GmbH, Hann, Germany) with two stainless ball of $7.0 \mathrm{~mm}$ diameter, into a stainless jar $(10 \mathrm{~mL})$ at a rate of 1800 rounds per minute $(30 \mathrm{~Hz})$ at room temperature. The final temperature in the reaction vessel $\left(40^{\circ} \mathrm{C}\right)$ was measured with a digital thermometer. All the nitrones $\mathbf{3}$ and $\mathbf{6}-$ 31 have been obtained as pure compounds and have been identified by comparison of their spectral and physical data with those reported in the literature. Analytical high performance liquid chromatography (HPLC) was performed on a Waters Millenium 717 equipped with Autosampler, with a variable wavelength diode detector using a CHROMOLITH RP18 column $(50 \times 4,6 \mathrm{~mm})$, flow $5 \mathrm{~mL} /$ min, linear gradient $\mathrm{CH}_{3} \mathrm{CN}$ in water $0-100 \%(+0.1 \% \mathrm{TFA})$ in $4.5 \mathrm{~min}$.

\subsection{General experimental procedure for the synthesis of nitrones 3 and 6-31 (Tables 1 and 2)}

\subsubsection{Method A: ball-milling conditions}

A mixture of aldehyde ( $0.5 \mathrm{mmol}, 1$ equiv), $\mathrm{N}$-substituted hydroxylamine hydrochloride $\left(0.5 \mathrm{mmol}, 1.0\right.$ equiv), and $\mathrm{NaHCO}_{3}$ ( $0.5 \mathrm{mmol}, 1.0$ equiv) were ball-milled at $30 \mathrm{~Hz}$ for $0.5-2 \mathrm{~h}$ (depending on the aldehyde, see Tables 1 and 2). When the reaction was complete, the reaction mixture was solubilized in $\mathrm{CH}_{2} \mathrm{Cl}_{2}$ and filtered on cotton to eliminate $\mathrm{NaCl}$. The filtrate was evaporated under vacuum to afford nitrones $\mathbf{3}$ and 6-31 with high purity. The yields are tabulated on Tables 1 and 2 .

\subsubsection{Method B: microwave conditions (only for nitrones}

\section{3, 6-8, and 15)}

A mixture of aldehyde ( $0.5 \mathrm{mmol}, 1$ equiv), $\mathrm{N}$-substituted hydroxylamine $\left(0.5 \mathrm{mmol}, 1.0\right.$ equiv), and $\mathrm{NaHCO}_{3} \quad(0.5 \mathrm{mmol}$, 1.0 equiv) were heated by microwave irradiation at $120^{\circ} \mathrm{C}$ (initial power $400 \mathrm{~W}$ ) in three runs of $1 \mathrm{~h}$ each. Temperature of $120^{\circ} \mathrm{C}$ was reached in less than $1 \mathrm{~min}$. After cooling, the reaction mixture was solubilized in $\mathrm{CH}_{2} \mathrm{Cl}_{2}$ and filtered on cotton to eliminate $\mathrm{NaCl}$. The filtrate was evaporated under vacuum to afford the corresponding nitrones. The yields are tabulated in Table 1 and were calculated by ${ }^{1} \mathrm{H}$ NMR using $\mathrm{CH}_{2} \mathrm{Br}_{2}(30 \mu \mathrm{L}, 0.43 \mathrm{mmol})$ as an internal standard.

\subsection{3. (Z)-N-Benzylidenemethylamine $\mathrm{N}$-oxide (3) (Table 1 , entry 1$)^{43,44}$}

Method A. The condensation reaction between benzaldehyde 1a and $\mathrm{N}$-methylhydroxylamine hydrochloride 2 afforded $56 \mathrm{mg}$ of $\mathbf{3}$ as a yellow solid in $82 \%$ yield. Mp $78-81{ }^{\circ} \mathrm{C}$ (lit. $\left.{ }^{45} 82-83{ }^{\circ} \mathrm{C}\right) ;{ }^{1} \mathrm{H}$ $\operatorname{NMR}\left(\mathrm{CDCl}_{3}\right) \delta 8.30-8.20(\mathrm{~m}, 2 \mathrm{H}), 7.37-7.40(\mathrm{~m}, 3 \mathrm{H}), 7.35(\mathrm{~s}, \mathrm{CH}=\mathrm{N}$, $1 \mathrm{H}), 3.87(\mathrm{~s}, 3 \mathrm{H}) ;{ }^{13} \mathrm{C} \mathrm{NMR}\left(\mathrm{CDCl}_{3}\right) \delta 135.30,130.49,128.49,54.44$; IR (KBr): 3416.3 (br), 3062.4 (w), 1596.7 (m), 1445.4 (w), 1165.5 (vs), 
943.1 (vs), 846.1 (w), $756.4(\mathrm{~m}), 693.6$ (s) $\mathrm{cm}^{-1}$; ESIMS m/z 136.1 $[\mathrm{M}+\mathrm{H}]^{+} ; \mathrm{FAB}(+) \mathrm{m} / z 136.1[\mathrm{M}+\mathrm{H}]^{+}$; HRMS Calcd for $\mathrm{C}_{8} \mathrm{H}_{10} \mathrm{NO}$ $[\mathrm{M}+\mathrm{H}]^{+}:$136.0762. Found 136.0769.

Method B. Yellow solid in $72 \%$ yield.

4.2.4. (Z)-N-Benzylidenebenzylamine $\mathrm{N}$-oxide (6) (Table 1, entry 2$)^{43,44}$

Method A. The condensation reaction between benzaldehyde 1a and $\mathrm{N}$-benzylhydroxylamine hydrochloride 4 afforded $93 \mathrm{mg}$ of $\mathbf{6}$ as a white solid in $88 \%$ yield. Mp $78-80{ }^{\circ} \mathrm{C}\left(\right.$ lit. $\left.^{46} 81-83{ }^{\circ} \mathrm{C}\right) ;{ }^{1} \mathrm{H} \mathrm{NMR}$ $\left(\mathrm{CDCl}_{3}\right) \delta 8.32-8.19(\mathrm{~m}, 2 \mathrm{H}), 7.37-7.51(\mathrm{~m}, 8 \mathrm{H}), 7.31(\mathrm{~s}, \mathrm{CH}=\mathrm{N}, 1 \mathrm{H})$, $5.08(\mathrm{~s}, 2 \mathrm{H}) ;{ }^{13} \mathrm{C} \mathrm{NMR}\left(\mathrm{CDCl}_{3}\right) \delta 134.48,130.31,130.40,129.23$, 128.97, 128.69, 128.47, 71.22; IR (KBr): 3184.0 (br), $3064.1(\mathrm{w})$, 3031.4, 2816.5 (w), 1582.8 (m), 1565.8, 1493.8 (w), 1457.6 (s), 1424.3 (m), $1320.8(\mathrm{~m}), 1299.5(\mathrm{w}), 1147.0$ (vs), 939.8 (vs), 815.9 (w), 756.4 (m), $817.8(\mathrm{~m}), 754.2(\mathrm{~m}), 703.6(\mathrm{~s}), 690.8(\mathrm{~s}) \mathrm{cm}^{-1}$; ESIMS m/z 212.1 $[\mathrm{M}+\mathrm{H}]^{+} ; \mathrm{FAB}(+) m / z 212.1[\mathrm{M}+\mathrm{H}]^{+}$; HRMS Calcd for $\mathrm{C}_{14} \mathrm{H}_{13} \mathrm{NO}$ $[\mathrm{M}+\mathrm{H}]^{+}:$212.1075. Found 212.1068.

Method $B$. White solid in $80 \%$ yield.

4.2.5. (Z)-N-Benzylidene-tert-butylamine $\mathrm{N}$-oxide (7)

(Table 1, entry 3) $47-49$

Method A. The condensation reaction between benzaldehyde 1a and $N$-tert-butylhydroxylamine hydrochloride 5 afforded $88 \mathrm{mg}$ of 7 as a pale brown solid in $100 \%$ yield. Mp $71-72{ }^{\circ} \mathrm{C}\left(\right.$ lit. $\left.^{50} 75-76{ }^{\circ} \mathrm{C}\right)$; ${ }^{1} \mathrm{H}$ NMR $\left(\mathrm{CDCl}_{3}\right) \delta 8.38-8.22(\mathrm{~m}, 2 \mathrm{H}), 7.58(\mathrm{~s}, \mathrm{CH}=\mathrm{N}, 1 \mathrm{H}), 7.42-7.38$ $(\mathrm{m}, 3 \mathrm{H}), 1.58\left(\mathrm{~s}, \mathrm{C}\left(\mathrm{CH}_{3}\right)_{3}, 9 \mathrm{H}\right) ;{ }^{13} \mathrm{C} \mathrm{NMR}\left(\mathrm{CDCl}_{3}\right) \delta 131.02,130.09$, 129.86, 128.77, 128.40, 70.78, 28.31; IR (KBr): 3421.04 (br), 2935.58 (w), $1579.0(\mathrm{~s}), 1562.6(\mathrm{~m}), 1444.4(\mathrm{~m}), 1415.6(\mathrm{~m}), 1364.8(\mathrm{~s}), 1193.3$ (w), 1118.6 (s), $1076.66(\mathrm{w}), 905.0(\mathrm{w}), 835.9(\mathrm{w}), 757.7(\mathrm{~m}), 696.0$ (m) $\mathrm{cm}^{-1}$; ESIMS $m / z$ 178.1 $[\mathrm{M}+\mathrm{H}]^{+}, 122.2\left[\mathrm{M}-\mathrm{C}\left(\mathrm{CH}_{3}\right)_{3}\right]^{+} ; \mathrm{FAB}(+)$ $m / z 178.1[\mathrm{M}+\mathrm{H}]^{+}$; HRMS Calcd for $\mathrm{C}_{11} \mathrm{H}_{16} \mathrm{NO}[\mathrm{M}+\mathrm{H}]^{+}: 178.1232$. Found 178.1217.

Method B. Pale brown solid in $74 \%$ yield.

\subsection{6. (Z)-N-(4-Cyanobenzylidene)methylamine $\mathrm{N}$-oxide $(\boldsymbol{8})$}

(Table 1 , entry 4$)^{24}$

Method $A$. The condensation reaction between aldehyde $\mathbf{1 b}$ and $\mathrm{N}$-methylhydroxylamine hydrochloride $\mathbf{2}$ afforded $74 \mathrm{mg}$ of $\mathbf{8}$ as a white solid in $93 \%$ yield. Mp $184-186{ }^{\circ} \mathrm{C}$ (lit. ${ }^{45} 187{ }^{\circ} \mathrm{C}$ ); ${ }^{1} \mathrm{H}$ NMR $\left(\mathrm{CDCl}_{3}\right) \delta 8.24(\mathrm{~d}, J=8.5 \mathrm{~Hz}, 2 \mathrm{H}), 7.64(\mathrm{~d}, J=8.5 \mathrm{~Hz}, 2 \mathrm{H}), 7.40(\mathrm{~s}$, $\mathrm{CH}=\mathrm{N}, 1 \mathrm{H}), 3.91(\mathrm{~s}, 3 \mathrm{H}) ;{ }^{13} \mathrm{C} \mathrm{NMR}\left(\mathrm{CDCl}_{3}\right) \delta 134.28,133.47,132.80$, 132.25, 128.30, 118.51, 113.03, 55.03; IR (KBr): 3416.2 (w), 2996.2 (w), 2223.3 (s), 1585.6 .0 (s), 1548.7 (s), 1442.5 (m), 1421.6 (m), $1185.6(\mathrm{~s}), 1167.1$ (s), $1095.3(\mathrm{w}), 947.2(\mathrm{~s}), 852.4(\mathrm{~s}), 590.7$ (s), 544.1 (s) $\mathrm{cm}^{-1}$; ESIMS $m / z 161.1[\mathrm{M}+\mathrm{H}]^{+} ; \mathrm{FAB}(+) \mathrm{m} / z 161.1[\mathrm{M}+\mathrm{H}]^{+}$; HRMS Calcd for $\mathrm{C}_{9} \mathrm{H}_{9} \mathrm{~N}_{2} \mathrm{O}[\mathrm{M}+\mathrm{H}]^{+}:$161.0715. Found 161.0713.

Method $B$. White solid in $64 \%$ yield.

\subsection{7. (Z)-N-(4-Cyanobenzylidene)benzylamine $\mathrm{N}$-oxide (9)}

(Table 1 , entry 5$)^{51}$

Method $A$. The condensation reaction between aldehyde $\mathbf{1 b}$ and $\mathrm{N}$-benzylhydroxylamine hydrochloride 4 afforded $117 \mathrm{mg}$ of $\mathbf{9}$ as a pale yellow solid in $99 \%$ yield. Mp $140-142{ }^{\circ} \mathrm{C}$ (lit. ${ }^{51} 143-150{ }^{\circ} \mathrm{C}$ ); ${ }^{1} \mathrm{H}$ NMR $\left(\mathrm{CDCl}_{3}\right) \delta 8.32(\mathrm{~d}, J=8.6 \mathrm{~Hz}, 2 \mathrm{H}), 7.71(\mathrm{~d}, J=8.6 \mathrm{~Hz}, 2 \mathrm{H})$, 7.55-7.40 (m, 6H), $5.09(\mathrm{~s}, 2 \mathrm{H}) ;{ }^{13} \mathrm{C}$ NMR $\left(\mathrm{CDCl}_{3}\right) \delta 134.32,132.77$, 132.58, 132.16, 129.30, 129.08, 128.50, 128.05, 118.59, 112.85, 71.87; IR (KBr): 3065.3 (w), 2224.4 (s), 1573.4 (s), 1542.9 (w), 1448.3 (m), $1149.4(\mathrm{~s}), 937.4(\mathrm{~m}), 861.8(\mathrm{~s}), 698.1(\mathrm{~s}), 564.8(\mathrm{~m}) \mathrm{cm}^{-1}$; ESIMS $\mathrm{m} / z$ $237.0[\mathrm{M}+\mathrm{H}]^{+} ; \mathrm{FAB}(+) \mathrm{m} / z$ 237.1 $[\mathrm{M}+\mathrm{H}]^{+}$; HRMS Calcd for $\mathrm{C}_{15} \mathrm{H}_{13} \mathrm{~N}_{2} \mathrm{O}[\mathrm{M}+\mathrm{H}]^{+}:$237.1028. Found 237.1030.

\subsection{8. (Z)-N-(4-Nitrobenzylidene)methylamine $\mathrm{N}$-oxide (10)}

(Table 1, entry 6) $24,45,52$

Method A. The condensation reaction between aldehyde $\mathbf{1 c}$ and $\mathrm{N}$-methylhydroxylamine hydrochloride $\mathbf{2}$ afforded $87 \mathrm{mg}$ of $\mathbf{1 0}$ as a dark yellow solid in $94 \%$ yield. Mp $212-214{ }^{\circ} \mathrm{C}$ (lit. ${ }^{53} 217-218{ }^{\circ} \mathrm{C}$ ); ${ }^{1} \mathrm{H} \mathrm{NMR}\left(\mathrm{CDCl}_{3}\right) \delta 8.41(\mathrm{~d}, J=9.0 \mathrm{~Hz}, 2 \mathrm{H}), 8.29(\mathrm{~d}, J=9.0 \mathrm{~Hz}, 2 \mathrm{H}), 7.58$ $(\mathrm{s}, \mathrm{CH}=\mathrm{N}, 1 \mathrm{H}), 3.98(\mathrm{~s}, 3 \mathrm{H}) ;{ }^{13} \mathrm{C} \mathrm{NMR}\left(\mathrm{CDCl}_{3}\right) \delta 147.22,135.40$, 132.57, 128.46, 123.72, 54.55; IR ( $\mathrm{KBr}): 3425.0$ (w), 3112.8 (w), $1598.1(\mathrm{~m}), 1510.7$ (s), 1341.33 (s), 1185.18 (m), 1165.7 (m), 1110.9 (m), $947.8(\mathrm{~m}), 867.7(\mathrm{~m}), 687.8(\mathrm{w}) \mathrm{cm}^{-1}$; ESIMS m/z $181.1[\mathrm{M}+\mathrm{H}]^{+}$; $\mathrm{FAB}(+) \mathrm{m} / z$ 181.1 $[\mathrm{M}+\mathrm{H}]^{+}$; HRMS Calcd for $\mathrm{C}_{8} \mathrm{H}_{9} \mathrm{~N}_{2} \mathrm{O}_{3}[\mathrm{M}+\mathrm{H}]^{+}$: 181.0613. Found 181.0608 .

\subsection{9. (Z)-N-(4-Iodobenzylidene)methylamine $\mathrm{N}$-oxide (11)}

(Table 1, entry 7)

Method $A$. The condensation reaction between aldehyde $\mathbf{1 d}$ and $\mathrm{N}$-methylhydroxylamine hydrochloride $\mathbf{2}$ afforded $131 \mathrm{mg}$ of $\mathbf{1 1}$ as a pale yellow solid in $100 \%$ yield. Mp $143-147^{\circ} \mathrm{C} ;{ }^{1} \mathrm{H}$ NMR $\left(\mathrm{CDCl}_{3}\right)$ $\delta 8.01(\mathrm{~d}, J=8.6 \mathrm{~Hz}, 2 \mathrm{H}), 7.81(\mathrm{~d}, J=8.6 \mathrm{~Hz}, 2 \mathrm{H}), 7.33(\mathrm{~s}, \mathrm{CH}=\mathrm{N}, 1 \mathrm{H})$, $3.87(\mathrm{~s}, 3 \mathrm{H}) ;{ }^{13} \mathrm{C} \mathrm{NMR}\left(\mathrm{CDCl}_{3}\right) \delta 137.72,134.23,129.83,129.67,96.37$, 54.63; IR (KBr): 3444.1 (w), $3073.9(\mathrm{w}), 1590.4(\mathrm{~m}), 1573.29(\mathrm{~m})$, 1403.0 (w), 1182.9 (s), 1167.9 (s), 946.9 (m), 831.1 (s), 678.9 (w) $\mathrm{cm}^{-1}$; ESIMS $m / z 262.0[\mathrm{M}+\mathrm{H}]^{+}$; FAB $(+) \mathrm{m} / z 262.0[\mathrm{M}+\mathrm{H}]^{+}$; HRMS Calcd for $\mathrm{C}_{8} \mathrm{H}_{9} \mathrm{INO}[\mathrm{M}+\mathrm{H}]^{+}:$261.9729. Found 261.9736.

\subsubsection{0. (Z)-N-(3-Iodobenzylidene)methylamine $\mathrm{N}$-oxide (12)}

(Table 1, entry 8)

Method A. The condensation reaction between aldehyde $\mathbf{1 e}$ and $\mathrm{N}$-methylhydroxylamine hydrochloride $\mathbf{2}$ afforded $124 \mathrm{mg}$ of $\mathbf{1 2}$ as a white solid in $94 \%$ yield. Mp 93-95 ${ }^{\circ} \mathrm{C} ;{ }^{1} \mathrm{H}$ NMR $\left(\mathrm{CDCl}_{3}\right) \delta 8.63(\mathrm{~s}$, $1 \mathrm{H}), 8.18(\mathrm{~d}, J=7.9 \mathrm{~Hz}, 1 \mathrm{H}), 7.75(\mathrm{~d}, J=7.9 \mathrm{~Hz}, 1 \mathrm{H}), 7.32(\mathrm{~s}, \mathrm{CH}=\mathrm{N}, 1 \mathrm{H})$, $7.18(\mathrm{t}, J=7.9 \mathrm{~Hz}, 1 \mathrm{H}) ;{ }^{13} \mathrm{C} \mathrm{NMR}\left(\mathrm{CDCl}_{3}\right) \delta 139.45,136.58,133.61$, 130.1, 127.39, 94.22, 54.66; IR (KBr): 3430.8 (br), 3077.4 (w), 1575.1 (w), $1384.2(\mathrm{~s}), 1173.8(\mathrm{~m}), 1161.7(\mathrm{w}), 948.2(\mathrm{~m}), 807.9(\mathrm{~s}), 688.8(\mathrm{w})$ $\mathrm{cm}^{-1}$; ESIMS $m / z$ 261.9.0 $[\mathrm{M}+\mathrm{H}]^{+} ; \mathrm{FAB}(+) \mathrm{m} / \mathrm{z} 262.0[\mathrm{M}+\mathrm{H}]^{+}$; HRMS Calcd for $\mathrm{C}_{8} \mathrm{H}_{9} \mathrm{INO}[\mathrm{M}+\mathrm{H}]^{+}$: 261.9729. Found 261.9732 .

\subsubsection{1. (Z)-N-(2-Iodobenzylidene)methylamine $N$-oxide (13)}

(Table 1, entry 9)

Method A. The condensation reaction between aldehyde $\mathbf{1 f}$ and $\mathrm{N}$-methylhydroxylamine hydrochloride $\mathbf{2}$ afforded $131 \mathrm{mg}$ of $\mathbf{1 3}$ as a white solid in $100 \%$ yield. Mp $116-118{ }^{\circ} \mathrm{C} ;{ }^{1} \mathrm{H}$ NMR $\left(\mathrm{CDCl}_{3}\right) \delta 9.23$ $(\mathrm{d}, J=7.5 \mathrm{~Hz}, 1 \mathrm{H}), 7.95(\mathrm{~d}, J=7.5 \mathrm{~Hz}, 1 \mathrm{H}), 7.78(\mathrm{~s}, \mathrm{CH}=\mathrm{N}, 1 \mathrm{H}), 7.45(\mathrm{t}$, $J=7.5 \mathrm{~Hz}, 1 \mathrm{H}), 7.11(\mathrm{t}, J=7.5 \mathrm{~Hz}, 1 \mathrm{H}) ;{ }^{13} \mathrm{C} \mathrm{NMR}\left(\mathrm{CDCl}_{3}\right) \delta 139.70$, 138.57, 132.30, 131.59, 129.18, 128.47, 98.97, 55.22; IR (KBr): 3432.4 (br), $3085.6(\mathrm{w}), 1574.1(\mathrm{w}), 1406.2(\mathrm{w}), 1166.3(\mathrm{~s}), 946.9(\mathrm{~m}), 748.9$ (m) $\mathrm{cm}^{-1}$; ESIMS $m / z$ 261.9.0 $[\mathrm{M}+\mathrm{H}]^{+}, 135.2[(\mathrm{M}-\mathrm{I})+\mathrm{H}]^{+} ; \mathrm{FAB}(+)$ $m / z 262.0[\mathrm{M}+\mathrm{H}]^{+}$; HRMS Calcd for $\mathrm{C}_{8} \mathrm{H}_{9} \mathrm{INO}[\mathrm{M}+\mathrm{H}]^{+}: 261.9729$. Found 261.9729.

\subsubsection{2. (Z)-N-(4-Methylbenzylidene)methylamine $\mathrm{N}$-oxide (14)}

(Table 1, entry 10$)^{24,52,54}$

Method A. The condensation reaction between aldehyde $\mathbf{1 g}$ and $\mathrm{N}$-methylhydroxylamine hydrochloride 2 afforded $72 \mathrm{mg}$ of $\mathbf{1 4}$ as a white solid in $96 \%$ yield. Mp $118-120{ }^{\circ} \mathrm{C}$ (lit. $\left.{ }^{25} 119-121{ }^{\circ} \mathrm{C}\right) ;{ }^{1} \mathrm{H}$ $\operatorname{NMR}\left(\mathrm{CDCl}_{3}\right) \delta 8.18(\mathrm{~d}, J=7.2 \mathrm{~Hz}, 2 \mathrm{H}), 7.43(\mathrm{~s}, \mathrm{CH}=\mathrm{N}, 1 \mathrm{H}), 7.21(\mathrm{~d}$, $J=7.2 \mathrm{~Hz}, 2 \mathrm{H}), 3.83(\mathrm{~s}, 3 \mathrm{H}), 2.42\left(\mathrm{~s}, \mathrm{NCH}_{3}, 3 \mathrm{H}\right) ;{ }^{13} \mathrm{C} \mathrm{NMR}\left(\mathrm{CDCl}_{3}\right)$ $\delta 140.87,135.27,129.70,128.94,127.82,54.19,21.65 ; \mathrm{IR}(\mathrm{KBr}): 3438.8$ (br), $3086.1(\mathrm{w}), 1586.3(\mathrm{w}), 1414.7(\mathrm{~s}), 1163.2(\mathrm{~s}), 944.2(\mathrm{~s}), 839.6(\mathrm{~s})$, $588.4(\mathrm{~m}), 501.9(\mathrm{~s}) \mathrm{cm}^{-1}$; ESIMS $\mathrm{m} / \mathrm{z} 200.0[2 \mathrm{M}+\mathrm{H}]^{+}, 150.1$ $[\mathrm{M}+\mathrm{H}]^{+} ; \mathrm{FAB}(+) \mathrm{m} / z$ 150.1 $[\mathrm{M}+\mathrm{H}]^{+}$; HRMS Calcd for $\mathrm{C}_{9} \mathrm{H}_{12} \mathrm{NO}$ $[\mathrm{M}+\mathrm{H}]^{+}:$150.0919. Found 150.0911.

\subsubsection{3. (Z)-N-(4-Methylbenzylidene)benzylamine $\mathrm{N}$-oxide (15)}

(Table 1 , entry 11$)^{55}$

Method $A$. The condensation reaction between aldehyde $\mathbf{1 g}$ and $\mathrm{N}$-benzylhydroxylamine hydrochloride $\mathbf{4}$ afforded $99 \mathrm{mg}$ of $\mathbf{1 5}$ as a white solid in $88 \%$ yield. Mp $116-118{ }^{\circ} \mathrm{C} ;{ }^{1} \mathrm{H}$ NMR $\left(\mathrm{CDCl}_{3}\right) \delta 8.15(\mathrm{~d}$, $J=7.7 \mathrm{~Hz}, 2 \mathrm{H}), 7.59-7.34(\mathrm{~m}, 5 \mathrm{H}), 7.26(\mathrm{~d}, J=7.7 \mathrm{~Hz}, 2 \mathrm{H}), 5.12(\mathrm{~s}, 2 \mathrm{H})$, $2.45\left(\mathrm{~s}, \mathrm{NCH}_{3}, 3 \mathrm{H}\right) ;{ }^{13} \mathrm{C} \mathrm{NMR}\left(\mathrm{CDCl}_{3}\right) \delta 140.96,134.38,133.38,129.22$, 
129.17, 128.95, 128.69, 127.78, 71.01, 21.68; IR (KBr): 3066 (w), $3032.1(\mathrm{w}), 1609.2(\mathrm{w}), 1497.7(\mathrm{~s}), 1458.2(\mathrm{~s}), 1431.2(\mathrm{w}), 939.2(\mathrm{~s})$, $849.6(\mathrm{~s}), 829.4(\mathrm{~m}) \mathrm{cm}^{-1}$; ESIMS $\mathrm{m} / z \quad 451.2[2 \mathrm{M}+\mathrm{H}]^{+}, 248.1$ $[\mathrm{M}+\mathrm{Na}]^{+}, 226.0[\mathrm{M}+\mathrm{H}]^{+} ; \mathrm{FAB}(+) \mathrm{m} / z 226.1[\mathrm{M}+\mathrm{H}]^{+}$; HRMS Calcd for $\mathrm{C}_{15} \mathrm{H}_{16} \mathrm{NO}[\mathrm{M}+\mathrm{H}]^{+}:$226.1232. Found 226.1222.

Method $B$. White solid in 65\% yield.

\subsubsection{4. (Z)-N-(3-Methylbenzylidene)methylamine $N$-oxide (16)}

(Table 1, entry 12)

Method $A$. The condensation reaction between aldehyde $\mathbf{1 h}$ and $\mathrm{N}$-methylhydroxylamine hydrochloride $\mathbf{2}$ afforded $68 \mathrm{mg}$ of $\mathbf{1 6}$ as deep orange oil in 91\% yield. ${ }^{1} \mathrm{H}$ NMR $\left(\mathrm{CDCl}_{3}\right) \delta 8.13(\mathrm{~s}, 1 \mathrm{H}), 7.97(\mathrm{~d}$, $J=7.6 \mathrm{~Hz}, 1 \mathrm{H}), 7.38(\mathrm{~m}, 2 \mathrm{H}), 7.28(\mathrm{~m}, 2 \mathrm{H}), 3.95\left(\mathrm{~s}, \mathrm{NCH}_{3}, 3 \mathrm{H}\right), 2.45$ (s, $3 \mathrm{H}) ;{ }^{13} \mathrm{C} \mathrm{NMR}\left(\mathrm{CDCl}_{3}\right) \delta 138.12,135.55,131.37,130.33,128.88$, 128.35, 127.18, 125.78, 54.32, 21.41; IR (KBr): 3404.7 (br), 2929.1 (m), $1653.11(\mathrm{w}), 1597.6(\mathrm{~m}), 1413.7$ (s), 1173.4 (s), 1159.8 (s), 946.4 (m), $909.5(\mathrm{w}), 786.8(\mathrm{~m}), 693.2(\mathrm{~s}) \mathrm{cm}^{-1}$; ESIMS $\mathrm{m} / \mathrm{z} 299.2$ $[2 \mathrm{M}+\mathrm{H}]^{+}, 172.2[\mathrm{M}+\mathrm{Na}]^{+}, 150.1[\mathrm{M}+\mathrm{H}]^{+} ; \mathrm{FAB}(+) \mathrm{m} / \mathrm{z} 150.1$ $[\mathrm{M}+\mathrm{H}]^{+}$; HRMS Calcd for $\mathrm{C}_{9} \mathrm{H}_{12} \mathrm{NO}[\mathrm{M}+\mathrm{H}]^{+}$: 150.0919. Found 150.0929 .

4.2.15. (Z)-N-(Pyridine-4-ylmethylidene)methylamine $N$-oxide (17) (Table 2, entry 1)

Method A. The condensation reaction between aldehyde $\mathbf{1 i}$ and $\mathrm{N}$-methylhydroxylamine hydrochloride $\mathbf{2}$ afforded $65 \mathrm{mg}$ of $\mathbf{1 7}$ as deep yellow solid in $96 \%$ yield. Mp $106-108{ }^{\circ} \mathrm{C} ;{ }^{1} \mathrm{H}$ NMR $\left(\mathrm{CDCl}_{3}\right)$ $\delta 8.65$ (br s, $2 \mathrm{H}), 8.05(\mathrm{~d}, J=5.5 \mathrm{~Hz}, 2 \mathrm{H}), 7.45(\mathrm{~s}, \mathrm{CH}=\mathrm{N}, 1 \mathrm{H}), 3.95$ (s, $\left.\mathrm{NCH}_{3}, 3 \mathrm{H}\right) ;{ }^{13} \mathrm{C} \mathrm{NMR}\left(\mathrm{CDCl}_{3}\right) \delta 150.41,136.76,133.14,121.25$, 55.11; IR (KBr): 3412.6 (br), 1648.2 (w), 1594.3 (s), 1414.2 (s), 1173.3 (s), $948.1(\mathrm{~m}), 847.7(\mathrm{~m}), 534.7(\mathrm{~m}) \mathrm{cm}^{-1}$; ESIMS m/z $137.1[\mathrm{M}+\mathrm{H}]^{+}$; $\mathrm{FAB}(+) \mathrm{m} / z$ 137.1 $[\mathrm{M}+\mathrm{H}]^{+}$; HRMS Calcd for $\mathrm{C}_{7} \mathrm{H}_{9} \mathrm{~N}_{2} \mathrm{O}[\mathrm{M}+\mathrm{H}]^{+}$: 137.0715. Found 137.0695.

4.2.16. (Z)-N-(Pyridine-4-ylmethylidene)benzylamine $N$-oxide (18) (Table 2, entry 2)

Method $A$. The condensation reaction between aldehyde $1 \mathbf{i}$ and $\mathrm{N}$ benzylhydroxylamine hydrochloride $\mathbf{4}$ afforded $106 \mathrm{mg}$ of $\mathbf{1 8}$ as deep brown solid in $100 \%$ yield. Mp $103-105{ }^{\circ} \mathrm{C} ;{ }^{1} \mathrm{H}$ NMR $\left(\mathrm{CDCl}_{3}\right)$ $\delta 8.78$ (br s, 2H), 8.05 (br s, 2H), 7.45 (br s, 6H), 5.15 (s, 2H); ${ }^{13} \mathrm{C} \mathrm{NMR}$ $\left(\mathrm{CDCl}_{3}\right) \delta 150.26,136.71,132.59,132.22,129.28,129.15,129.07$, 128.94, 128.58, 128.45, 126.75, 121.58, 72.00; IR (KBr): 3422.8 (w), 3052.5 (w), $1561.2(\mathrm{~m}), 1459.1(\mathrm{~m}), 1430.9(\mathrm{~m}), 1155.3(\mathrm{~m}), 1205.3(\mathrm{~s})$, $1155.3(\mathrm{~s}), 863.8(\mathrm{~s}), 769.9(\mathrm{~m}), 719.9(\mathrm{~s}), 573.6(\mathrm{~m}), 517.7(\mathrm{~m}), 497.1$ (m) $\mathrm{cm}^{-1}$; ESIMS $\mathrm{m} / z 213.2[\mathrm{M}+\mathrm{H}]^{+} ; \mathrm{FAB}(+) \mathrm{m} / \mathrm{z} 213.1[\mathrm{M}+\mathrm{H}]^{+}$; HRMS Calcd for $\mathrm{C}_{13} \mathrm{H}_{13} \mathrm{~N}_{2} \mathrm{O}[\mathrm{M}+\mathrm{H}]^{+}:$213.1028. Found 213.1046 .

\subsubsection{7. (Z)-N-(Pyridine-4-ylmethylidene)-tert-butylamine $\mathrm{N}$-oxide} (19) (Table 2, entry 3) $)^{49,57}$

Method $A$. The condensation reaction between aldehyde $\mathbf{1 i}$ and $\mathrm{N}$-tert-butylhydroxylamine hydrochloride 5 afforded $87 \mathrm{mg}$ of $\mathbf{1 9}$ as deep orange solid in $98 \%$ yield. Mp 84-86 ${ }^{\circ} \mathrm{C}\left(\right.$ lit. $\left.^{57} 99-101{ }^{\circ} \mathrm{C}\right) ;{ }^{1} \mathrm{H}$ $\operatorname{NMR}\left(\mathrm{CDCl}_{3}\right) \delta 8.89$ (br s, $\left.2 \mathrm{H}\right), 8.18($ br s, $2 \mathrm{H}), 7.58(\mathrm{~s}, \mathrm{CH}=\mathrm{N}, 1 \mathrm{H})$, $1.58(\mathrm{~s}, 9 \mathrm{H}) ;{ }^{13} \mathrm{C} \mathrm{NMR}\left(\mathrm{CDCl}_{3}\right) \delta 149.20,137.12,128.17,123.46,72.32$, 53.49, 28.45, 28.20, 27.95; IR (KBr): 3422.1 (w), 2977.7 (w), 1587.9 $(\mathrm{s}), 141.6(\mathrm{~s}), 1363.6(\mathrm{~m}), 1188.7(\mathrm{~m}), 1136.0(\mathrm{~s}), 988.8(\mathrm{~m}), 836.6(\mathrm{~s})$, $544.1(\mathrm{~m}), 529.6(\mathrm{~m}) \mathrm{cm}^{-1}$; ESIMS $\mathrm{m} / \mathrm{z} 179.0[\mathrm{M}+\mathrm{H}]^{+}, 123.2$ $\left[\left(\mathrm{M}-\mathrm{C}\left(\mathrm{CH}_{3}\right)_{3}\right)+\mathrm{H}\right]^{+} ; \mathrm{FAB}(+) \mathrm{m} / z$ 179.1 $[\mathrm{M}+\mathrm{H}]^{+}$; HRMS Calcd for $\mathrm{C}_{10} \mathrm{H}_{15} \mathrm{~N}_{2} \mathrm{O}[\mathrm{M}+\mathrm{H}]^{+}:$179.1184. Found 179.1187.

\subsubsection{8. (Z)-N-(Pyridine-3-ylmethylidene)methylamine $N$-oxide (20)} (Table 2, entry 4$)^{58}$

Method A. The condensation reaction between aldehyde $\mathbf{1 j}$ and $\mathrm{N}$-methylhydroxylamine hydrochloride $\mathbf{2}$ afforded $59 \mathrm{mg}$ of $\mathbf{2 0}$ as deep violet solid in $87 \%$ yield. Mp $74-76{ }^{\circ} \mathrm{C}$ (lit. ${ }^{58} 74-76{ }^{\circ} \mathrm{C}$ ); ${ }^{1} \mathrm{H}$ $\operatorname{NMR}\left(\mathrm{CDCl}_{3}\right) \delta 8.95(\mathrm{~m}, 2 \mathrm{H}), 8.56(\mathrm{~d}, 1 \mathrm{H}), 7.43(\mathrm{~s}, \mathrm{CH}=\mathrm{N}, 1 \mathrm{H}), 7.35$ (dd, $J=4.8 \mathrm{~Hz}$ and $J=7.9 \mathrm{~Hz}, 1 \mathrm{H}), 3.93(\mathrm{~s}, 3 \mathrm{H}) ;{ }^{13} \mathrm{C} \mathrm{NMR}\left(\mathrm{CDCl}_{3}\right)$ $\delta$ 150.59, 149.58, 134.46, 132.28, 126.99, 123.53, 54.59; IR (KBr): 3408.8 (br s), 1649.3 (m), 1588.7 (m), 1483.9 (w), 1414.5 (s), 1192.9 (m), $1168.4(\mathrm{~s}), 944.9(\mathrm{~m}), 704.1(\mathrm{~s}), 536.6(\mathrm{~m}) \mathrm{cm}^{-1}$; ESIMS m/z $137.1[\mathrm{M}+\mathrm{H}]^{+} ; \mathrm{FAB}(+) \mathrm{m} / z 137.1[\mathrm{M}+\mathrm{H}]^{+}$; HRMS Calcd for $\mathrm{C}_{7} \mathrm{H}_{9} \mathrm{~N}_{2} \mathrm{O}$ $[\mathrm{M}+\mathrm{H}]^{+}:$137.0715. Found 137.0707.

4.2.19. (Z)-N-(Pyridine-2-ylmethylidene)methylamine $N$-oxide (21) (Table 2, entry 5$)^{39}$

Method $A$. The condensation reaction between aldehyde $\mathbf{1 k}$ and $\mathrm{N}$-methylhydroxylamine hydrochloride $\mathbf{2}$ afforded $65 \mathrm{mg}$ of $\mathbf{2 1}$ as deep orange solid in $96 \%$ yield. Mp $48-50{ }^{\circ} \mathrm{C}$ (lit. $\left.{ }^{39} 48-50{ }^{\circ} \mathrm{C}\right) ;{ }^{1} \mathrm{H}$ $\operatorname{NMR}\left(\mathrm{CDCl}_{3}\right) \delta 9.12(\mathrm{~d}, J=8.0 \mathrm{~Hz}, 1 \mathrm{H}), 8.62(\mathrm{~d}, J=4.8 \mathrm{~Hz}, 1 \mathrm{H}), 7.81(\mathrm{t}$, $J=7.6 \mathrm{~Hz}, 1 \mathrm{H}), 7.70(\mathrm{~s}, \mathrm{CH}=\mathrm{N}, 1 \mathrm{H}), 7.32-7.28(\mathrm{~m}, 1 \mathrm{H}), 3.93(\mathrm{~s}, 3 \mathrm{H})$; ${ }^{13} \mathrm{C} \mathrm{NMR}\left(\mathrm{CDCl}_{3}\right) \delta 149.56,149.42,136.81,136.62,124.33,123.60$, 54.81; IR (KBr): 3409.6 (br s), 1658.8 (m), 1587.4 (m), 1567.7 (m), $1437.9(\mathrm{~m}), 1409.1(\mathrm{~s}), 1167.3(\mathrm{~s}), 1145.5(\mathrm{~s}), 950.0(\mathrm{~s}), 774.6(\mathrm{~s}), 545.6$ (m) $\mathrm{cm}^{-1}$; ESIMS m/z $159.1[\mathrm{M}+\mathrm{Na}]^{+}, 137.1[\mathrm{M}+\mathrm{H}]^{+} ; \mathrm{FAB}(+) \mathrm{m} / \mathrm{z}$ $137.1[\mathrm{M}+\mathrm{H}]^{+}$; HRMS Calcd for $\mathrm{C}_{7} \mathrm{H}_{9} \mathrm{~N}_{2} \mathrm{O}[\mathrm{M}+\mathrm{H}]^{+}:$137.0715. Found 137.0717.

4.2.20. (Z)-N-(Pyridine-2-ylmethylidene)-tert-butylamine $\mathrm{N}$-oxide (22) (Table 2, entry 6) ${ }^{49}$

Method A. The condensation reaction between aldehyde $\mathbf{1 k}$ and $\mathrm{N}$-tert-butylhydroxylamine hydrochloride $\mathbf{5}$ afforded $63 \mathrm{mg}$ of $\mathbf{2 2}$ as white needles in $71 \%$ yield. Mp 63-65 ${ }^{\circ} \mathrm{C}$ (lit. $\left.{ }^{49} 62-63{ }^{\circ} \mathrm{C}\right) ;{ }^{1} \mathrm{H}$ NMR $\left(\mathrm{CDCl}_{3}\right) \delta 9.25(\mathrm{~d}, J=8.1 \mathrm{~Hz}, 1 \mathrm{H}), 8.62(\mathrm{~d}, J=4.8 \mathrm{~Hz}, 1 \mathrm{H}), 7.92$ (s, $\mathrm{CH}=\mathrm{N}, 1 \mathrm{H}), 7.81(\mathrm{dt}, J=1.7 \mathrm{~Hz}$ and $7.8 \mathrm{~Hz}, 1 \mathrm{H}), 7.32(\mathrm{~m}, 1 \mathrm{H}), 1.65(\mathrm{~s}$, $9 \mathrm{H}) ;{ }^{13} \mathrm{C} \mathrm{NMR}\left(\mathrm{CDCl}_{3}\right) \delta 150.13,149.37,136.84,131.55,124.02$, 123.56, 71.65, 28.47, 28.23, 27.96; IR (KBr): 3428.5 (br s), 2980.4 (m), $1560.4(\mathrm{~m}), 1437.5(\mathrm{~m}), 1407.1(\mathrm{~s}), 1198.1(\mathrm{~s}), 1122.5(\mathrm{~s}), 913.0(\mathrm{~s})$, $816.4(\mathrm{~s}), 744.6(\mathrm{~s}) \mathrm{cm}^{-1}$; ESIMS $\mathrm{m} / \mathrm{z} 179.2[\mathrm{M}+\mathrm{H}]^{+}, 123.2$ $\left[\left(\mathrm{M}-\mathrm{C}\left(\mathrm{CH}_{3}\right)_{3}\right)+\mathrm{H}\right]^{+} ; \mathrm{FAB}(+) \mathrm{m} / z$ 179.1 $[\mathrm{M}+\mathrm{H}]^{+}$; HRMS Calcd for $\mathrm{C}_{10} \mathrm{H}_{15} \mathrm{~N}_{2} \mathrm{O}[\mathrm{M}+\mathrm{H}]^{+}:$179.1184. Found 179.1201.

\subsubsection{1. (Z)-N-(Fur-2-ylmethylidene)methylamine $N$-oxide (23)} (Table 2, entry 7$)^{39,43}$

Method $A$. The condensation reaction between aldehyde $\mathbf{1 1}$ and $\mathrm{N}$-methylhydroxylamine hydrochloride $\mathbf{2}$ afforded $50 \mathrm{mg}$ of $\mathbf{2 3}$ as a white solid in $80 \%$ yield. Mp $79-81{ }^{\circ} \mathrm{C}$ (lit. $\left.{ }^{59} 91-92{ }^{\circ} \mathrm{C}\right) ;{ }^{1} \mathrm{H}$ NMR $\left(\mathrm{CDCl}_{3}\right) \delta 7.75(\mathrm{~d}, J=3.4 \mathrm{~Hz}, 1 \mathrm{H}), 7.53(\mathrm{~s}, \mathrm{CH}=\mathrm{N}, 1 \mathrm{H}), 7.47(\mathrm{br} \mathrm{s}, 1 \mathrm{H})$ $6.55(\mathrm{dd}, J=3.3 \mathrm{~Hz}$ and $1.7 \mathrm{~Hz}, 1 \mathrm{H}), 3.81(\mathrm{~s}, 3 \mathrm{H}) ;{ }^{13} \mathrm{C} \mathrm{NMR}\left(\mathrm{CDCl}_{3}\right)$ $\delta 146.70,143.61,126.23,115.24,112.29,52.76$; IR (KBr): 3390.7 (br s), $3156.4(\mathrm{~m}), 3110.6(\mathrm{~m}), 1666.4(\mathrm{w}), 1620.1(\mathrm{~m}), 1607.7$ (m), 1561.53 (w), $1481.45(\mathrm{~m}), 1411.9(\mathrm{~m}), 1400.3(\mathrm{~m}), 1231.1(\mathrm{~s}), 1141.8(\mathrm{~s}), 1010.9$ (s), $939.7(\mathrm{~s}), 825.7(\mathrm{~m}), 767.6(\mathrm{~s}), 593.3(\mathrm{~m}), 555.2(\mathrm{~m}) \mathrm{cm}^{-1}$; ESIMS $\mathrm{m} / \mathrm{z} 126.0[\mathrm{M}+\mathrm{H}]^{+} ; \mathrm{FAB}(+) \mathrm{m} / \mathrm{z} 126.1[\mathrm{M}+\mathrm{H}]^{+}$; HRMS Calcd for $\mathrm{C}_{6} \mathrm{H}_{8} \mathrm{NO}_{2}[\mathrm{M}+\mathrm{H}]^{+}:$126.0555. Found 126.0563.

\subsubsection{2. (Z)-N-(Fur-2-ylmethylidene)benzylamine $N$-oxide (24)}

(Table 2, entry 8$)^{60}$

Method $A$. The condensation reaction between aldehyde $\mathbf{1 1}$ and $\mathrm{N}$-benzylhydroxylamine hydrochloride 4 afforded $94 \mathrm{mg}$ of $\mathbf{2 4}$ as a light brown solid in $94 \%$ yield. Mp $85-88{ }^{\circ} \mathrm{C}\left(\right.$ lit. $\left.^{60} 88^{\circ} \mathrm{C}\right) ;{ }^{1} \mathrm{H}$ NMR $\left(\mathrm{CDCl}_{3}\right) \delta 7.79$ (br s, $\left.1 \mathrm{H}\right), 7.65-7.32$ (br s, 7H), 7.62 (br s, $\left.1 \mathrm{H}\right), 5.06$ (s, $2 \mathrm{H}) ;{ }^{13} \mathrm{C} \mathrm{NMR}\left(\mathrm{CDCl}_{3}\right) \delta 146.83,143.72,132.84,129.41,129.04$, 128.44, 125.24, 115.37, 112.34, 69.57; IR (KBr): 3442.6 (br w), 3191.0 (w), $3066.4(\mathrm{w}), 1582.5(\mathrm{~m}), 1558.1(\mathrm{~m}), 1485.4(\mathrm{~s}), 1438.4(\mathrm{~m})$, $1427.83(\mathrm{~m}), 1137.06(\mathrm{~s}), 1008.6(\mathrm{~m}), 930.2(\mathrm{~m}), 916.7(\mathrm{~m}), 814.2(\mathrm{~m})$, $737.5(\mathrm{~s}), 703.4(\mathrm{~s}), 671.8(\mathrm{~m}), 593.2(\mathrm{~m}), 559.3(\mathrm{~m}) \mathrm{cm}^{-1}$; ESIMS $\mathrm{m} / z$ $224.1[\mathrm{M}+\mathrm{Na}]^{+}, 202.2[\mathrm{M}+\mathrm{H}]^{+} ; \mathrm{FAB}(+) \mathrm{m} / z 202.1[\mathrm{M}+\mathrm{H}]^{+}$; HRMS Calcd for $\mathrm{C}_{12} \mathrm{H}_{12} \mathrm{NO}_{2}[\mathrm{M}+\mathrm{H}]^{+}:$202.0868. Found 202.0861.

4.2.23. (Z)-N-(Thiophen-2-ylmethylidene)methylamine $N$-oxide (25) (Table 2, entry 9)

Method A. The condensation reaction between aldehyde $\mathbf{1} \mathbf{m}$ and $\mathrm{N}$-methylhydroxylamine hydrochloride $\mathbf{2}$ afforded $65 \mathrm{mg}$ of $\mathbf{2 5}$ as 
a white solid in $92 \%$ yield. Mp $115-117{ }^{\circ} \mathrm{C} ;{ }^{1} \mathrm{H}$ NMR $\left(\mathrm{CDCl}_{3}\right) \delta 7.89$ (s, $1 \mathrm{H}), 7.50$ (br d, $1 \mathrm{H}), 7.45$ (br d, $1 \mathrm{H}), 7.17$ (dd, $J=3.8 \mathrm{~Hz}, J=5.0 \mathrm{~Hz}, 1 \mathrm{H})$, $3.92(\mathrm{~s}, 3 \mathrm{H}) ;{ }^{13} \mathrm{C}$ NMR $\left(\mathrm{CDCl}_{3}\right) \delta 132.41,130.82,129.25,128.99$, 126.47, 51.71; IR (KBr): 3425.1 (br s), 3064.0 (w), 2967.64 (w), $1585.4(\mathrm{~s}), 1389.7(\mathrm{~s}), 1253.6(\mathrm{~m}), 1228.8(\mathrm{~m}), 1162.4(\mathrm{~s}), 1092.9(\mathrm{w})$, $1044.8(\mathrm{~m}), 952.9(\mathrm{~s}), 855.4(\mathrm{~s}), 763.6(\mathrm{~s}), 702.9(\mathrm{~s}), 599.8(\mathrm{~m}), 537.3$ (m) $\mathrm{cm}^{-1}$; ESIMS $\mathrm{m} / z 142.1[\mathrm{M}+\mathrm{H}]^{+} ; \mathrm{FAB}(+) \mathrm{m} / z 142.0[\mathrm{M}+\mathrm{H}]^{+}$; HRMS Calcd for $\mathrm{C}_{6} \mathrm{H}_{8} \mathrm{NOS}[\mathrm{M}+\mathrm{H}]^{+}$: 142.0327. Found 142.0314.

\subsubsection{4. (Z)-N-(Benzofuran-2-ylmethylidene)methylamine $\mathrm{N}$-oxide}

(26) (Table 2, entry 10)

Method $A$. The condensation reaction between aldehyde $\mathbf{1 n}$ and $\mathrm{N}$-methylhydroxylamine hydrochloride $\mathbf{2}$ afforded $87 \mathrm{mg}$ of $\mathbf{2 6}$ as a pale yellow solid in $100 \%$ yield. Mp $108-110{ }^{\circ} \mathrm{C} ;{ }^{1} \mathrm{H} \mathrm{NMR}\left(\mathrm{CDCl}_{3}\right)$ $\delta 8.18$ (br s, 1H), 7.71-7.67 (m, 1H), 7.51-7.45 (m, 1H), 7.41 (dd, $J=6.96 \mathrm{~Hz}$ and $1.41 \mathrm{~Hz}, 1 \mathrm{H}), 7.33(\mathrm{dd}, J=4.71 \mathrm{~Hz}$ and $1.41 \mathrm{~Hz}, 1 \mathrm{H})$, 7.28 (dd, $J=6.96 \mathrm{~Hz}$ and $1.33 \mathrm{~Hz}, 1 \mathrm{H}), 3.92(\mathrm{~s}, 3 \mathrm{H}) ;{ }^{13} \mathrm{C} \mathrm{NMR}\left(\mathrm{CDCl}_{3}\right)$ $\delta$ 154.40, 147.68, 128.35, 126.54, 126.24, 123.42, 122.44, 111.08, 110.91, 53.44; IR (KBr): 3419.5 (br w), 3141.1 (w), 3028.9 (w), 2947.4 (w), $1593.6(\mathrm{~m}), 1543.4(\mathrm{~m}), 1450.5(\mathrm{~m}), 1409.6(\mathrm{~s}), 1392.6(\mathrm{~m})$, $1343.9(\mathrm{~m}), 1266.1(\mathrm{~m}), 1247.3(\mathrm{~s}), 1203.5(\mathrm{~s}), 1134.6(\mathrm{~m}), 955.9(\mathrm{~s})$ 867.7 (s), 780.1 (s), 753.9 (s), $747.3(\mathrm{~s}), 655.0(\mathrm{~m}), 518.6(\mathrm{~m}) \mathrm{cm}^{-1}$; ESIMS $m / z 176.1[\mathrm{M}+\mathrm{H}]^{+} ; \mathrm{FAB}(+) m / z 176.1[\mathrm{M}+\mathrm{H}]^{+}$; HRMS Calcd for $\mathrm{C}_{10} \mathrm{H}_{10} \mathrm{NO}_{2}[\mathrm{M}+\mathrm{H}]^{+}:$176.0712. Found 176.0713.

\subsubsection{5. (E)-N-(Napht-2-ylmethylidene)methylamine $\mathrm{N}$-oxide (27)}

(Table 2, entry 11$)^{42}$

Method $A$. The condensation reaction between aldehyde $\mathbf{1 0}$ and $\mathrm{N}$-methylhydroxylamine hydrochloride $\mathbf{2}$ afforded $85 \mathrm{mg}$ of $\mathbf{2 7}$ as a deep yellow solid in $92 \%$ yield. Mp $108-110{ }^{\circ} \mathrm{C}$ (lit. $\left.{ }^{39} 106-108{ }^{\circ} \mathrm{C}\right)$; ${ }^{1} \mathrm{H}$ NMR $\left(\mathrm{CDCl}_{3}\right) \delta 9.22(\mathrm{~s}, \mathrm{CH}=\mathrm{N}, 1 \mathrm{H}), 7.95-7.88(\mathrm{~m}, 1 \mathrm{H}), 7.85-7.78$ $(\mathrm{m}, 3 \mathrm{H}), 7.55-7.45(\mathrm{~m}, 3 \mathrm{H}), 3.92(\mathrm{~s}, 3 \mathrm{H}) ;{ }^{13} \mathrm{C} \mathrm{NMR}\left(\mathrm{CDCl}_{3}\right) \delta 162.59$, $135.23,134.12,133.13,129.21,128.42,127.98,127.72,127.55,127.36$, 126.51, 125.66, 54.51; IR (KBr): 3420.6 (br w), 3078.5 (w), 3057.9 (w), $2996.8(\mathrm{w}), 2941.4(\mathrm{w}), 1578.2(\mathrm{~m}), 1566.5(\mathrm{w}), 1502.2(\mathrm{w})$, 1416.77 (s), 1404.3 (m), 1380.3 (m), 1364.2 (m), 1274.5 (w), 1125.5 (m), $968.8(\mathrm{~m}), 957.5(\mathrm{~m}), 904.9(\mathrm{~m}), 869.9(\mathrm{~s}), 841.9(\mathrm{~s}), 753.4(\mathrm{~s})$, $482.7(\mathrm{~s}) \mathrm{cm}^{-1}$; ESIMS $\mathrm{m} / z 371.1[\mathrm{M}+2 \mathrm{H}]^{+}, 208.1[\mathrm{M}+\mathrm{Na}]^{+}, 186.2$ $[\mathrm{M}+\mathrm{H}]^{+} ; \mathrm{FAB}(+) m / z 186.1[\mathrm{M}+\mathrm{H}]^{+}$; HRMS Calcd for $\mathrm{C}_{12} \mathrm{H}_{12} \mathrm{NO}$ $[\mathrm{M}+\mathrm{H}]^{+}:$186.0919. Found 186.0918.

\subsubsection{6. (Z)- $\mathrm{N}$-(Napht-2-ylmethylidene)benzylamine $\mathrm{N}$-oxide (28)}

(Table 2 , entry 12$)^{28,55}$

Method $A$. The condensation reaction between aldehyde $\mathbf{1 0}$ and $\mathrm{N}$-benzylhydroxylamine hydrochloride $\mathbf{4}$ afforded $131 \mathrm{mg}$ of $\mathbf{2 8}$ as a pale orange solid in $100 \%$ yield. Mp $104-106{ }^{\circ} \mathrm{C}$ (lit. ${ }^{28} 107-$ $\left.108{ }^{\circ} \mathrm{C}\right) ;{ }^{1} \mathrm{H}$ NMR $\left(\mathrm{CDCl}_{3}\right) \delta 9.25(\mathrm{~s}, \mathrm{CH}=\mathrm{N}, 1 \mathrm{H}), 7.92-7.77(\mathrm{~m}, 4 \mathrm{H})$, 7.68-7.32 (m, 8H), $5.11(\mathrm{~s}, 2 \mathrm{H}) ;{ }^{13} \mathrm{C}$ NMR $\left(\mathrm{CDCl}_{3}\right) \delta 134.34,134.14$, 133.40, 133.14, 129.56, 129.26, 129.00, 128.61, 128.32, 127.94, 127.73, 127.56, 127.39, 126.54, 125.95, 71.28; IR (KBr): 3441.5 (br w), 3056.8 (w), $3028.9(\mathrm{w}), 1572.4(\mathrm{~m}), 1497.1(\mathrm{w}), 1451.5(\mathrm{~m}), 1353.9(\mathrm{~m})$, $1229.9(\mathrm{~m}), 1183.6(\mathrm{~m}), 1161.3(\mathrm{~m}), 1142.2(\mathrm{~m}), 945.5(\mathrm{~m}), 901.6(\mathrm{~m})$, $866.6(\mathrm{~s}), 829.9(\mathrm{~m}), 732.2(\mathrm{~s}), 701.4(\mathrm{~s}), 479.3(\mathrm{~s}) \mathrm{cm}^{-1}$; ESIMS $\mathrm{m} / z$ $523.0[\mathrm{M}+2 \mathrm{H}]^{+}, 262.1[\mathrm{M}+\mathrm{H}]^{+} ; \mathrm{FAB}(+) \mathrm{m} / z 262.1[\mathrm{M}+\mathrm{H}]^{+}$; HRMS Calcd for $\mathrm{C}_{18} \mathrm{H}_{16} \mathrm{NO}[\mathrm{M}+\mathrm{H}]^{+}:$262.1232. Found 262.1234.

4.2.27. (Z)-N-(Quinol-3-ylmethylidene)methylamine $\mathrm{N}$-oxide (29) (Table 2, entry 13)

Method A. The condensation reaction between aldehyde $\mathbf{1 p}$ and $\mathrm{N}$-methylhydroxylamine hydrochloride $\mathbf{2}$ afforded $84 \mathrm{mg}$ of $\mathbf{2 9}$ as a bright yellow solid in 95\% yield. Mp $120-122{ }^{\circ} \mathrm{C} ;{ }^{1} \mathrm{H} \mathrm{NMR}\left(\mathrm{CDCl}_{3}\right)$ $\delta 9.91(\mathrm{~s}, 1 \mathrm{H}), 8.88(\mathrm{~s}, 1 \mathrm{H}), 8.12(\mathrm{~d}, J=8.4 \mathrm{~Hz}, 1 \mathrm{H}), 7.94(\mathrm{~d}, J=8.1 \mathrm{~Hz}$, $1 \mathrm{H}), 7.78(\mathrm{td}, J=8.4 \mathrm{~Hz}$ and $1.5 \mathrm{~Hz}, 1 \mathrm{H}), 7.68(\mathrm{~s}, 1 \mathrm{H}), 7.61(\mathrm{td}, J=8.4 \mathrm{~Hz}$ and $1.5 \mathrm{~Hz}, 1 \mathrm{H}), 3.93(\mathrm{~s}, 3 \mathrm{H}) ;{ }^{13} \mathrm{C}$ NMR $\left(\mathrm{CDCl}_{3}\right) \delta 150.01,148.01$, 134.52, 132.54, 130.71, 129.09, 128.92, 127.48, 127.27, 123.76, 54.51; IR (KBr): 3398.4 (br s), 3291.4 (s), 3095.3 (m), 3040.6 (m), 3001.1 (m), $1666.6(\mathrm{~s}), 1601.9(\mathrm{~m}), 1572.0(\mathrm{~m}), 1498.5(\mathrm{~m}), 1420.9(\mathrm{~s}), 1348.1$ (s), $1195.9(\mathrm{w}), 1158.9(\mathrm{~s}), 949.0(\mathrm{~m}), 921.8(\mathrm{~s}), 862.2(\mathrm{w}), 782.9(\mathrm{~s})$, $754.3(\mathrm{~s}), 649.1(\mathrm{~m}), 637.6(\mathrm{~m}), 468.9(\mathrm{~m}) \mathrm{cm}^{-1}$; ESIMS m/z 187.1 $[\mathrm{M}+\mathrm{H}]^{+} ; \mathrm{FAB}(+) \mathrm{m} / z$ 187.1 $[\mathrm{M}+\mathrm{H}]^{+}$; HRMS Calcd for $\mathrm{C}_{11} \mathrm{H}_{11} \mathrm{~N}_{2} \mathrm{O}$ $[\mathrm{M}+\mathrm{H}]^{+}:$187.0871. Found 187.0872.

\subsubsection{8. (Z)-N-(n-Butylidene)methylamine $\mathrm{N}$-oxide (30)}

(Table 2, entry 14)

Method $A$. The condensation reaction between aldehyde $\mathbf{1 q}$ and $\mathrm{N}$-methylhydroxylamine hydrochloride $\mathbf{2}$ afforded $47 \mathrm{mg}$ of $\mathbf{3 0}$ as a colorless oil in $93 \%$ yield. ${ }^{1} \mathrm{H}$ NMR $\left(\mathrm{CDCl}_{3}\right) \delta 6.71(\mathrm{t}, J=5.8 \mathrm{~Hz}, 1 \mathrm{H})$, $3.71(\mathrm{~s}, 3 \mathrm{H}$ ), 2.51 (br q, $J=7.4 \mathrm{~Hz}$ and $1.3 \mathrm{~Hz}, 2 \mathrm{H}$ ), 1.58 (septet, $J=7.5 \mathrm{~Hz}, 2 \mathrm{H}), 0.99(\mathrm{t}, J=7.3 \mathrm{~Hz}, 3 \mathrm{H}) ;{ }^{13} \mathrm{C} \mathrm{NMR}\left(\mathrm{CDCl}_{3}\right) \delta 140.63$, 52.32, 28.73, 18.89, 13.93; IR (KBr): 3399.4 (br s), 2963.7 (s), 2875.4 (s), $1660.6(\mathrm{~s}), 1459.1(\mathrm{~s}), 1386.9(\mathrm{~m}), 1080.3(\mathrm{w}), 947.2(\mathrm{w}), 627.1(\mathrm{w})$ $\mathrm{cm}^{-1}$; ESIMS $m / z$ 203.2 $[\mathrm{M}+2 \mathrm{H}]^{+}, 102.0[\mathrm{M}+\mathrm{H}]^{+} ; \mathrm{FAB}(+) \mathrm{m} / z 102.1$ $[\mathrm{M}+\mathrm{H}]^{+}$; HRMS Calcd for $\mathrm{C}_{5} \mathrm{H}_{12} \mathrm{NO}[\mathrm{M}+\mathrm{H}]^{+}$: 102.0910 . Found 102.0922 .

\subsubsection{9. (Z)-N-(n-Heptylidene)methylamine $N$-oxide (31)}

(Table 2, entry 15$)^{43}$

Method A. The condensation reaction between aldehyde $\mathbf{1 r}$ and $\mathrm{N}$-methylhydroxylamine hydrochloride $\mathbf{2}$ afforded $64 \mathrm{mg}$ of $\mathbf{3 1}$ as a colorless oil in $90 \%$ yield. ${ }^{1} \mathrm{H}$ NMR $\left(\mathrm{CDCl}_{3}\right) \delta 6.67(\mathrm{t}, J=5.8 \mathrm{~Hz}, 1 \mathrm{H})$, 4.71 (s, 3H), 2.45 (br q, J=6.8 Hz, 2H), $1.55(\mathrm{~m}, 2 \mathrm{H}), 1.50-1.20(\mathrm{~m}$, $6 \mathrm{H}), 0.89(\mathrm{t}, J=7.1 \mathrm{~Hz}, 3 \mathrm{H}) ;{ }^{13} \mathrm{C} \mathrm{NMR}\left(\mathrm{CDCl}_{3}\right) \delta 140.92,52.31,31.44$, 29.11, 26.85, 25.43, 22.47, 13.98; IR (KBr): 3297.6 (br s), 2927.3 (s), 2860.1 (s), 1668.1 (s), 1461.33 (s), 1378.9 (w), $1102.4(\mathrm{w}), 947.8$ (w), $728.48(\mathrm{w}) \mathrm{cm}^{-1}$; ESIMS $\mathrm{m} / \mathrm{z} 287.2[\mathrm{M}+2 \mathrm{H}]^{+}, 144.2[\mathrm{M}+\mathrm{H}]^{+}$; $\mathrm{FAB}(+) \mathrm{m} / z$ 144.1 $[\mathrm{M}+\mathrm{H}]^{+}$; HRMS Calcd for $\mathrm{C}_{8} \mathrm{H}_{18} \mathrm{NO}[\mathrm{M}+\mathrm{H}]^{+}$: 144.1388. Found 144.1378 .

\section{Acknowledgements}

We thank Dr. Lydie Viau from the Institut Charles Gerhardt (UMR 5253, CMOS group, Montpellier, France) for DSC experiments, MENRT, CNRS, the Ligue Contre le Cancer and the Fondation d'Entreprise EADS for financial support.

\section{References and notes}

1. Kaupp, G.; Naimi-Jamal, M. R.; Ren, H.; Zoz, H. Technologies Based on SelfPropagating and Mechanochemical Reactions for Environmental Protection; Cao, G., Delogu, F., Orrù, R., Eds.; Research Signpost: Kerala, 2003; pp 83-100.

2. Kipp, S.; Sepelàk, V.; Becker, K. D. Chem. Unserer Zeit 2005, 39, 384-392.

3. Kaupp, G. Top. Curr. Chem. 2005, 254, 95-183.

4. Rodrìguez, B.; Bruckmann, A.; Rantanen, T.; Bolm, C. Adv. Synth. Catal. 2007, 349, 2213-2233.

5. Komatsu, K. Top. Curr. Chem. 2005, 254, 185-206.

6. Zhang, Z.; Gao, J.; Xia, J.-J.; Wang, G.-W. Org. Biomol. Chem. 2005, 3, 1617-1619.

7. Kaupp, G.; Naimi-Jamal, M. R.; Stepanenko, V. Chem.-Eur. J. 2003, 9, 4156-4160.

8. Kaupp, G.; Naimi-Jamal, M. R.; Schmeyers, J. Tetrahedron 2003, 59, 3753-3760.

9. Raston, C. L.; Scott, J. L. Green Chem. 2000, 2, 49-52.

10. Rodrìguez, B.; Rantanen, T.; Bolm, C. Angew. Chem., Int. Ed. 2006, 45, 69246926; Rodrìguez, B.; Bruckmann, A.; Bolm, C. Chem.-Eur. J. 2007, 13, 47104722 .

11. Balema, V. P.; Wiench, J. W.; Pruski, M.; Pecharsky, V. K. J. Am. Chem. Soc. 2002, $124,6244-6245$

12. Rasmussen, M. O.; Axelsson, O.; Tanner, D. Synth. Commun. 1997, 27, 4027-4030.

13. Tullberg, E.; Schacher, F.; Peters, D.; Frejd, T. Synthesis 2006, 1183-1189.

14. Tullberg, E.; Peters, D.; Frejd, T. J. Organomet. Chem. 2004, 689, 3778-3781.

15. Merino, P. Padwa, A., Ed.; Science of Synthesis; Thieme: Stuttgart, 2004; Vol. 27, pp 511-580.

16. Young, I. S.; Kerr, M. A. Angew. Chem., Int. Ed. 2003, 26, 3023-3026.

17. Masson, G.; Py, S.; Vallée, Y. Angew. Chem., Int. Ed. 2002, 41, 1772-1775.

18. Cardona, F.; Goti, A. Angew. Chem., Int. Ed. 2005, 44, 7832-7835. 
19. Zhang, H.; Joseph, J.; Vasquez-Vivar, J.; Karoui, H.; Nsanzumuhire, C.; Martàsek, P.; Tordo, P.; Kalyanaraman, B. FEBS Lett. 2000, 473, 58-62.

20. Floyd, R. A. Aging Cell 2006, 5, 51-57.

21. Green, A. R.; Ashwood, T.; Odergren, T.; Jackson, D. M. Pharmacol. Ther. 2003 $100,195-214$

22. Tice, C. M.; Ganem, B. J. Org. Chem. 1983, 48, 5048-5050.

23. Torssell, K.; Zeuthen, O. Acta Chem. Scand. Ser. B 1978, B32, 118-124.

24. Chan, K. S.; Yeung, W.-K.; Chan, R.-J.; Wang, T.-C.; Mak, W. J. Org. Chem. 1995, 60, 1741-1747.

25. For an example of synthesis of nitrones in a mortar, using an excess of hydroxylamine and in the presence of molecular sieves, see: Bigdeli, M. A.; Nikje, M. M. A. Monatsh. Chem. 2001, 132, 1547-1549.

26. Breuer, E. I. The Chemistry of Amino, Nitroso and Nitro Compounds and Their Derivatives; Patai, S., Ed.; Wiley: New York, NY, 1982; p 459.

27. Shailaja, M. M. A.; Rao, B. V. Synlett 2005, 1176-1178.

28. Soldaini, G.; Cardona, F.; Goti, A. Org. Lett. 2007, 9, 473-476.

29. Martiny, L.; Jørgensen, K. A. J. Chem. Soc., Perkin Trans. 1 1995, 699-704.

30. Lin, Y.-M.; Miller, M. J. J. Org. Chem. 2001, 66, 8282-8285.

31. Anastas, P. T.; Heine, L. G.; Williamson, T. C. ACS Symposium Series; Oxford University Press: Oxford, 2000; Vol. 767, p 298.

32. For experimental temperature data see the table in Supplementary data.

33. Lalynaraman, B.; Joseph, J.; Parthasarathy, S. FEBS Lett. 1991, 280, 17-20.

34. Floyd, R. A.; Hansley, K.; Jaffery, F.; Maidt, L.; Robonson, K.; Pye, Q.; Stewart, C. Life Sci. 1999, 65, 1893-1899.

35. Banerji, A.; Biswas, P. K.; Sengupta, P.; Dasgupta, S.; Gupta, M. Indian J. Chem. Sect. B: Org. Chem. Incl. Med. Chem. 2004, 43B, 880-881.

36. Microwaves in Organic Synthesis; Loupy, A., Ed.; Wiley-VCH: Weinheim, 2006.

37. Kim, S.; de A. Vilela, G. V. M.; Bouajila, J.; Dias, A. G.; Cyrino, F. Z. G. A.; Bouskela, E.; Costa, P. R. R.; Nepveu, F. Bioorg. Med. Chem. 2007, 15, 3572-3578 and references cited therein.

38. Villamena, F. A.; Dickman, M. H.; Crist, D. R. Inorg. Chem. 1998, 37, 1446-1453.

39. Shimizu, T.; Ishizaki, M.; Nitada, N. Chem. Pharm. Bull. 2002, 50, 908-921.
40. Hassan, A.; Wazeer, M. I. M.; Saeed, M. T.; Siddiqui, M. N.; Ali, S. A. J. Phys. Org. Chem. 2000, 13, 443-451.

41. Boyle, L. W.; Peagram, M. J.; Whitham, G. H. J. Chem. Soc. B 1971, 17281733.

42. Lipczynska-Kochany, E.; Kochany, J. J. Photochem. Photobiol., A: Chem. 1988, 45 65-79.

43. Deshong, P.; Leginus, J. M. J. Org. Chem. 1984, 49, 3421-3423.

44. Evans, D. A.; Song, H.-J.; Fandrick, K. R. Org. Lett. 2006, 8, 3351-3354.

45. Yijima, C.; Tsujimoto, T.; Suoa, K.; Yamauchi, M. Bull. Chem. Soc. Jpn. 1986, 59 2165-2170.

46. Cope, A. C.; Haven, A. C., Jr. J. Am. Chem. Soc. 1950, 72, 4896-4903.

47. Murahashi, S.; Mitsui, H.; Shiota, T.; Tsuda, T.; Watanabe, S. J. Org. Chem. 1990 $55,1736-1744$.

48. Zajac, W. W.; Walters, T. R.; Darcy, M. G. J. Org. Chem. 1988, 53, 5856-5860.

49. Shimizu, M.; Shibuya, I.; Taguchi, Y.; Hamakawa, S.; Suzuki, K.; Hayakawa, T. J. Chem. Soc., Perkin Trans. 1 1997, 3491-3492.

50. Emmons, W. D. J. Am. Chem. Soc. 1957, 79, 6522-6524.

51. Yamada, Y. M. A.; Tabata, H.; Ichinohe, M.; Takahashi, H.; Ikegami, S. Tetrahedron 2004, 60, 4087-4096.

52. Colonna, S.; Pironti, V.; Carrea, G.; Pasta, P.; Zambianchi, F. Tetrahedron 2004, 60 569-575.

53. Hwu, J. R. J. Chem. Soc., Perkin Trans. 1 1989, 1823-1831.

54. Castro, C.; Dixon, M.; Erden, I.; Ergonenc, P.; Keeffe, J. R.; Sukhovitsky, A. J. Org. Chem. 1989, 54, 3732-3738.

55. Kano, T.; Hashimoto, T.; Maruoka, K. J. Am. Chem. Soc. 2005, 127, 11926 11927.

57. Janzen, E. G.; Dudley, R. L.; Shetty, R. V. J. Am. Chem. Soc. 1979, 101, $243-245$.

58. Dagne, E.; Castagnoli, N. J. J. Med. Chem. 1972, 15, 356-360.

59. Goldschimdt, G.; Zanoli, E. Ber. Dtsch. Chem. Ges. 1892, 25, 2573-2593.

60. Dondoni, A.; Franco, S.; Junquera, F.; Merchàn, F.; Merino, P.; Tejero, T. Synth. Commun. 1994, 24, 2537-2550. 